УДК 902.01

ББК 63.4

https://doi.org/10.24852/2587-6112.2020.6.198.223

\title{
ПРЕДМЕТЫ ВООРУЖЕНИЯ И КОНСКОГО СНАРЯЖЕНИЯ ХАЗАРСКОГО ВРЕМЕНИ (СРЕДНЕЕ ТЕЧЕНИЕ СЕВЕРСКОГО ДОНЦА)
}

\author{
(C2020 г. Э.Е. Кравченко
}

Статья посвящена находкам предметов вооружения и конского снаряжения, выявленным на памятниках салтово-маяцкой культуры, расположенных в среднем течении р. Северский Донец. В верхнем ее течении (в пределах лесостепной зоны) эти предметы являются частой находкой и встречаются в основном в захоронениях катакомбных и кремационных некрополей. В степи они попадаются реже, что вызвало появление версий о слабом знакомстве проживавшего здесь населения с военным делом. Анализ материалов, выявленных в среднем течении Северского Донца, показывает несостоятельность указанных точек зрения. На расположенных здесь памятниках предметы вооружения и конского снаряжения встречаются достаточно часто. Так, на крупном поселении у с. Маяки Славянского р-на количество предметов этой категории составляет около $20 \%$ от общего количества находок металлических изделий. Данный вывод вполне согласуется с наличием в рассматриваемом регионе группы укрепленных поселений (Донецких городищ), оборонять которые без значительного воинского контингента не представляется возможным. Вполне логично, что большая часть находок предметов вооружения сконцентрирована именно на этих памятниках.

Ключевые слова: Северский Донец, хазарское время, городища, предметы вооружения, конское снаряжение, сабли, копья, стрелы, удила, стремена.

\section{ITEMS OF WEAPONS AND HORSE EQUIPMENT OF THE KHAZAR TIME (MIDDLE STREAM OF THE SEVERSKY DONETS)}

\section{E.E. Kravchenko}

The article is dedicated to weapons and horse equipment discovered at the monuments of the Saltovo-Mayaki culture located in the middle stream of the Seversky Donets river. In the upstream (within the forest-steppe zone) these items are generally found in the burials of catacomb and cremation necropolises. In the steppe, they are less frequently discovered, which accounts for the versions concerning the poor familiarization of the local population with military art. An analysis of the materials discovered in the middle stream of the Seversky Donets demonstrates the inconsistency of these viewpoints. Weapons and horse equipment items are rather often found at the monuments located in this area. Thus, in a large settlement near Mayaki village of Slavyansky District, the number of items from this category is about $20 \%$ of the total number of the discovered metal items. This conclusion is quite consistent with the concept of the presence of a group of fortified settlements (Donetsk fortified settlements) in the region, which could be defended without a significant military contingent. It is rather logical that the majority of discovered weapon items are concentrated at these monuments.

Keywords: archaeology, Seversky Donets, Khazar period, ancient fortified settlements, weapons, horse equipment, sabres, spears, arrows, bits, stirrups.

Среди материалов, происходящих с памятников салтово-маяцкой культуры (далее СМК), выделяются две группы: предметы вооружения и конского снаряжения. Они являются частой находкой в захоронениях катакомбных и кремационных некрополей лесостепи (Аксенов, 2005, а, б; 2017; Крыганов, 1989). Присутствуют они и в составе т. н. «комплексов», назначение которых не совсем ясно (Аксенов, Колода, 2017; Колода, 2014, c. 54-55). На поселениях их находят реже. Публикации и анализу многочисленных материалов, происходящих с лесостепных памят- ников, посвящен ряд работ (Крыганов, 1987; Комар, Сухобоков, 2000; Аксенов, 2005 а, б).

В пределах степной зоны наблюдается иная картина. Здесь, в области распространения памятников «болгарского» и «приазовского» вариантов СМК (по С.А. Плетневой, 1967; 2000) рассматриваемые материалы встречаются гораздо реже.

Характеристика предметов вооружения и конского снаряжения, происходящих из этого региона, была дана В.К. Михеевым (Михеев, 1985). Более детально эти же находки проанализировал А.В. Крыганов (Крыганов, 1987). 
В указанных работах они рассматривались вместе с материалами, обнаруженными на территории лесостепи, памятники которой существенно отличаются от объектов, расположенных в среднем течении Северского Донца.

В ряде работ делался акцент на количественных характеристиках. Так, в статье А.В. Комара и О.В. Сухобокова, посвящённой вооружению и военному делу Хазарского каганата, указывалось на редкость находок оружия и конского снаряжения на степных памятниках. Авторы почему-то связывали проживавшее здесь население с «в-н-н-д-р» (унногундурами) восточных источников (Комар, Сухобоков, 2000), для характеристики которых ими была приведена цитата из «Худуд аль- $а \overline{л а м »: ~ « О н и ~}$ - люди трусливые, слабые, бедные; доходных статей у них мало» (Бартольд, 1973, с.545). По непонятным причинам центральным городом в-н-н-д-ров было объявлено Царино городище (археологический комплекс у с. Маяки Славянского р-на Донецкой обл.). Вне сомнений, оно является видным, однако не самым значимым, как по размерам, так и по характеру укреплений, поселением на рассматриваемой нами территории.

Близкой позиции придерживался и К.И. Красильников, который связывал малое количество находок оружия и конского снаряжения в захоронениях могильников «зливкинского» типа с «исключительно гражданским составом населения» этих земель. Автор акцентировал внимание на том, что оружие встречается в единичных могилах; указывал на его «упрощённость, единичность экземпляров, отсутствие наступательных средств, например, сабель, луков», писал и о крайне малом количестве предметов, «относящихся к упряжи всадников». Эти признаки, по мнению автора, являются свидетельством отсутствия у степного населения кавалерии, наступательных средств, средств индивидуальной защиты (Красильников, 2010, с. 30). Показательно, что К.И. Красильниковым не учитывались материалы, происходящие с городищ, расположенных в среднем течении Северского Донца. В Луганской обл. факт присутствия городищ им отрицается (Красильников, 2010, c. 21). С чем сложно согласиться. В свое время C.А. Локтюшев упоминал о Рогаликском городище, расположенном у с. Петропавловка (Верхне-Теплянский р-н Луганской обл.) (Локтюшев, 2009, с. 299-300). В пользу наличия укреплённых поселений на этой террито- рии свидетельствуют характер расположения некоторых памятников, крупные размеры расчищенных на них построек (Красильников, 2010, с. 22), присутствие рядом с поселениями безынвентарных некрополей и данные топонимики региона.

В последние годы вышел ряд работ А.М. Голубева, в которых пишется, что степное население, по отношению к населению лесостепи, представляло собой низший социальный слой (Голубев, 2018, с. 392). Основанием для такого вывода послужило наличие в степных комплексах, которые автор считал кремациями, земледельческих и ремесленных орудий, при «минимальном присутствии вооружения». По его мнению, это может свидетельствовать «не о разноэтничном составе населения - носителей обряда кремации верхнего и среднего течения Северского Донца, а о его социальном и, возможно, племенном делении на два крыла «белых» и «черных», среди которых «белые» являлись военизированной верхушкой населения (Голубев, 2017, с. 63). Комментировать указанную точку зрения имеет смысл после рассмотрения вопроса о факте наличия или отсутствия захоронений, совершенных по обряду кремации, в пределах области распространения древностей «болгарского» варианта СМК. Данному вопросу будет посвящена отдельная работа.

Решение проблемы предлагается путём рассмотрения уже имеющихся материалов. Значительная часть их, в общем виде, ранее была опубликована (Михеев, 1985; Крыганов, 1987). Кроме этого, в последние десятилетия в среднем течении Северского Донца выявлено большое количество предметов вооружения и конского снаряжения хазарского времени. Основная часть находок обнаружена на двух крупных памятниках, которые подвергались многолетним раскопкам: археологических комплексах у с. Маяки и Сидорово Славянского р-на Донецкой обл. Они входят в группу из четырёх крупных укреплённых поселений, доминирующих над раннесредневековыми памятниками рассматриваемого нами региона.

\section{Общая характеристика памятников}

Археологический комплекс у с. Сидорово (Славянский $\mathrm{p}-\mathrm{H}$ Донецкой обл.) является крупнейшим из памятников на этой территории. Его площадь превышает 120 га. Населённый пункт существовал с кон. VIII до нач. $\mathrm{X}$ вв., когда в результате военных событий 
был оставлен. Следов разгрома на нем зафиксировано не было. На памятнике в продолжение многих лет велись раскопки, что ныне делает его одним из наиболее изученных объектов региона. При его исследованиях был выявлен богатый и разнообразный материал, в том числе предметы вооружения и конского снаряжения (Кравченко, 2020).

Археологический комплекс у с. Маяки (Славянский p-н Донецкой обл.). Местное население называет этот памятник «Царино городище». Указанное поселение (общая площадь ок. 70 га) существовало в продолжение всей эпохи Средневековья. Размеры памятника хазарского времени составляют не менее 45-50 га. Памятник сильно разрушен хозяйственной деятельностью, в связи с чем значительная часть выявленных на нем находок была обнаружена в подъёмном материале. Это создаёт трудности с отношением ряда предметов к тому или иному периоду его существования (см. ниже). Тем не менее значительное количество вещей было обнаружено при раскопках. Судя по материалам, полученным в результате многолетних исследований, Царино городище представляло крупный центр, население которого активно занималось ремеслами, в том числе металлообработкой. По сообщению В.К. Михеева, среди найденных им металлических предметов орудия кузнечного ремесла составляли не менее 8\% (Михеев, 1968, с. 26; 1985, с. 15-16). Населённый пункт прекратил существование в результате разгрома, сопровождающегося сильным пожаром, следы которого прослежены на различных участках поселения (Михеев, 1985, с. 18; Кравченко, Петренко, Шамрай, 2008, с. 8-12). Вероятно, именно этим мы обязаны наличию на памятнике большого количества разнообразного археологического материала, в числе которого присутствуют и интересующие нас категории предметов.

Поселение в ур. Государев Яр (неподалеку от с. Богородичное Славянского р-на). С этого памятника происходит крупная группа железных вещей (Давыденко, Гаврилова, 2011, с. 20-31). Указанные предметы (вначале 6 «комплексов») были найдены близ небольшого поселения, на противоположной стороне яра. В дальнейшем здесь было собрано ещё 2 «комплекса» (Колода, 2013, c. 80). Два «комплекса» и группа предметов, разбросанных по поверхности поселения, были выявлены в 2016 г. во время разведок (Дьячков, 2016, с. 223; Голубєв, 2017, с. 57-63).

Авторы по-разному характеризовали указанный памятник. Первооткрыватель видел здесь два самостоятельных объекта: «неукреплённое поселение на левом берегу балки и, видимо, погребально-поминальный комплекс на её противоположном правом берегу» (Давыденко, Гриб, 2011; Давыденко, Гаврилова, 2011). В.В. Колода вначале охарактеризовал его как могильник с захоронениями по обряду кремации (Колода, 2013, с. 73-81), а впоследствии как поселение и расположенные близ него тайники, связанные с сезонной обработкой земли (Колода, 2014, с. 54-55). В целом же все «комплексы» были найдены на памятнике в результате «разведок» или «шурфовки» и должным образом зафиксированы не были (Колода, 2013; Голубєв, 2017). Результатами этих работ является то, что ныне часть памятника, на которой они располагались, можно считать утраченной для науки. Поселение, расположенное на противоположном берегу яра, раскопкам не подвергалось.

«Клады железных вещей». Некоторые из «кладов» были выявлены при раскопках городища у с. Маяки (Михеев, 1963, с. 7; 1965, с. 18; 1966, с. 5-6, 9). Часть их была найдена неподалёку от поселений. Подавляющее большинство известных «кладов» найдено при помощи металлодетектора лицами, далёкими от науки. В процессе раскопок обнаружены единичные комплексы. С какой целью закапывались указанные предметы в землю, не ясно. Представляется, что эта категория материала неоднородна и содержит комплексы разного назначения. Часть «кладов» могла являться обрядовыми комплексами (поминальниками либо пожертвованиями). Часть могла быть вещами, спрятанными в минуты опасности.

Находки, выявленные в пределах древних лесных массивов. Составляют отдельную категорию материала. Предметы вооружения и конского снаряжения среди них присутствуют в достаточном количестве. Тем не менее практически все эти находки были выявлены во время грабительских раскопок, в результате чего точное место их обнаружения установить нет возможности. Научная ценность указанных материалов невелика и в данной работе рассматриваются только выделяющиеся из общей массы предметы.

Детали конской сбруи. Предметы, связанные с коневодством 
Конские путы встречены не на всех памятниках. Весомую долю находок они составляют в материалах археологического комплекса у с. Маяки. Пара конских пут находилась в составе клада железных вещей, обнаруженного при строительстве насосной станции на селище (Михеев, 1963, с. 7, табл. XVIII, 2-3). Путы и их фрагменты были найдены в подъемном материале на городище (Михеев, 1964, c. 5, табл. III, 25; Швецов, Кравченко, 1988; Матеріальна та духовна культура, 2017, ілл. 62) (рис. 1: 1-2), в культурном слое памятника (Михеев, 1965 , с. $8 ; 1966$, с. 6 , табл. Х, 4; 1968, с. 7, 11, табл. XXI, 13, 14), а также в заполнении его комплексов (Михеев, 1965, с. 13-14, 21, табл. XXV, 1, XXVI, 1; 1966, с. 13, табл. XIV; Ходжайов, Швецов, Ходжайова, Фризен, 2012, с. 134, рис. 14, 9). Двое конских пут разных типов зафиксировано на поселении в Государевом Яру. Они входили в состав «комплексов» № 2 и № 5 (Давыденко, Гриб, 2011 , с. 252 , рис. 3 , 9; с. 254 , рис. 8 , 6) (рис. 1: 4, 8). Ещё пара и фрагмент от третьих пут были подняты на территории Государева Яра при разведках (Голубєв, 2017, с. 57, рис. 1, 11-13).

Детали седел. Обычно представлены железной дужкой, которая оковывала верхнюю часть луки. Большая часть их находок концентрируется в материалах археологического комплекса у с. Маяки. Во время раскопок памятника В.К. Михеевым был найден ряд дужек от седел. Половинка дужки подобрана в 1965 г. на городище (Михеев, 1965, с. 3, табл. XXVII, 13). Оковка луки седла (Михеев, 1966, с. 14, табл. XV, 4), наряду с прочими предметами, среди которых были предметы вооружения и детали конского снаряжения, была обнаружена в заполнении ямы 53 (Михеев, 1966, с. 12-14) (рис. 3: 4), которую в дальнейшем автор раскопок относил к захоронениям по обряду кремации (Михеев, 1985, с. 17). В 1968 г. в слое раскопа VI (кв. 26/3-4) также была обнаружена железная оковка луки седла (Михеев, 1968, с. 19, табл. XXI, 7). Одна такая находка была сделана на городище краеведом из Славянска А.И. Духиным (рис. 1: 5). Она находилась в яме, размытой на полотне грунтовой дороги, пересекающей территорию городища, вместе с фрагментами крупной корчаги (Матеріальна та духовна культура, 2017, ілл. 59). Еще одна дужка была экспонирована на выставке, связанной с материалами Царина городища (Матеріальна та духовна культура, 2017, ілл. 59) (рис. 1: 7). Железная оковка седельной луки вместе с парой стремян и сбруйными кольцами была выявлена в материалах Государева Яра (в составе комплекса 2) (Колода, 2013, с. 79, илл. 8; 12, 3) (рис. 1: 3).

Как представляется, железную оковку имели далеко не все седла. В поминальном комплексе, расчищенном на склоне с городища Маяки в 2012 г., содержался комплект конской сбруи (удила, стремена, две подпружных пряжки) (рис. 4: 1-4), что предполагало и наличие седла, железных оковок от которого выявлено не было. Наличие же пятен горелой древесины на дне ямы может свидетельствовать в пользу того, что седло могло быть изготовлено из дерева и не иметь каких-либо металлических деталей.

Удила и стремена. На территории археологического комплекса у с. Маяки находки удил и стремян многочисленны. Они присутствуют в культурном слое поселения (Михеев, 1966, с. 11, табл. XVI, 1; Кравченко, Швецов, 1990). Достаточно много находок встречено в подъёмном материале (Михеев, 1963, с. 5, 7, табл. XIX, 1; XXIV, 1, 4; 1964, с. 5, табл. VIII, 1, 3; 1966, с. 2, табл. XVI, 2, 10). Хорошая подборка удил и стремян, собранных на территории городища, хранится в Славянском краеведческом музее (рис. 2: 1-9) и Святогорском историко-архитектурном заповеднике (Матеріальна та духовна культура, 2017, ілл. 54-55). Ряд предметов был обнаружен в составе археологических комплексов, расчищенных на памятнике. Так, кольцо от удил зафиксировано в засыпке ямы 12 (Михеев, 1964, с. 12-13, табл.VIII, 4). Пара стремян находилась в яме 23 (Михеев, 1964, с. 16, табл. VIII, 5-6). Стремена и удила присутствовали в яме 34 (Михеев, 1965, с. 13, табл. XII, 6-8), у западного края ямы 39 (Михеев, 1965, с. 16, табл. XII, 2-3), комплексе 6 (пара удил, четыре стремени, вместе с наконечником копья) (Михеев, 1966, с. 5, табл. XVI, 11-16), яме 53 (две пары стремян и удила) (Михеев, 1966, с. 14 , табл. XV, 1-3, 5-6) и яме 55 (Михеев, 1966, c. 16, табл. XVI, 3). Стремя вместе с конскими путами, сбруйным кольцом и подпружными пряжками находилось в составе т. н. «трупосожжения 3», расчищенного на могильнике памятника М.Л. Швецовым (Ходжайов, Швецов, Ходжайова, Фризен, 2012, с. 135, рис. 14, 7-9, 11-12). В комплексе 2012 г. в котле находились удила, а под котлом и на дне ямы лежала пара стремян и пара подпружных пряжек (рис. 4: 4) (Кравченко, Шамрай, 2014). 
В отличие от Маяков на Сидорово детали конской упряжи составляют небольшую группу предметов. В подъемном материале были зафиксированы двукольчатые удила (Кравченко, 2020, рис. 204, 16), фрагмент стремени (там же, рис. 204, 7), половинка удил с пальчатыми псалиями (там же, рис. 204, 6), сбруйные кольца (там же, рис. 204, 12-15) и железные пряжки. Кроме этого, в составе клада железных вещей, который был выявлен на городище в 2012 г., находились удила и пара стремян (Кравченко, 2020, рис. 167-168, 4-6).

Много предметов конской упряжи было выявлено в материалах Государева Яра. Фрагмент удил с пальчатым псалием был подобран на поверхности памятника во время разведок 2016 г. (Голубєв, 2017, рис. 1, 14). Пара стремян и сбруйное кольцо содержались в комплексе 5 (Давыденко, Гриб, 2011, с. 253-254, рис. 8, 1-2, 12). В т. н. «тайнике» находились половинка удил, целые удила с пальчатыми псалиями и подножка стремени (Голубєв, 2017, с. $59,61$, рис. $4,8,10,15)$. Пара стремян входила в состав комплекса 1, опубликованного В.В. Колодой. Пара стремян и сбруйные кольца входили и в комплекс 2 (Колода, 2013, с. 77, 79 , илл. 3, 7, 1-4; илл.8, 12, 1-2, 4-5).

Удила и стремена присутствуют в большинстве «кладов» железных вещей. Так, пара стремян входила в состав «клада», выявленного автором в 1981 г. на селище археологического комплекса у с. Маяки. Пара стремян находилась в «кладе», обнаруженном в 2008 г. близ поселения Выдылыха в Теплинском лесу. В состав клада из г. Николаевка Славянского р-на Донецкой обл. входили 7 стремян (Кравченко, 2020, рис. 164, 7-8, 10, 13-16), фрагменты 4 удил с пальчатыми псалиями (Кравченко, 2020, рис. 164, 1-4) и крупная, вероятно, сбруйная, пряжка (Кравченко, 2020, рис. 164,12$)$.

К числу предметов, связанных с конской сбруей, вероятно, относятся два предмета. Один из них был выявлен в составе поминального комплекса, найденного в 2012 г. на склоне городища у с. Маяки (Кравченко, Шамрай, 2014, с. 184, илл. 6, 8) (рис. 4: 6). Второй предмет входил в состав «клада» железных вещей, обнаруженного у г. Николаевка (Кравченко, Петренко, Шамрай, 2010, с. 4, рис. 29, 1). Они представляли собой выпуклые железные бляхи, диаметром 9,5-11 см. По нашему мнению, указанные бляхи могли находиться в центральной части кожаного нагрудника лошади, к которому они крепились при помощи металлической обоймы. Обломки такого крепления (куска железной полосы с отверстиями для заклёпок) входили в состав клада у г. Николаевка (рис. 4: 5).

Кроме вышеописанных предметов на памятниках в большом количестве присутствуют сбруйные кольца, подпружные пряжки и детали украшения ременной упряжи.

Пряжки являются частыми находками на рассматриваемых нами памятниках. Основная часть их представлена арочными пряжками (Кравченко, 2020, рис. 204, 1-4), которые могли использоваться как для поясов, так и для крепления ремней конской сбруи (рис. 5: 3-5, 8). В пользу этого свидетельствует присутствие таких пряжек в комплексах вместе с деталями конской упряжи (Кравченко, Шамрай, 2014, с. 185, илл. 3-4) (рис. 4: 4). Реже встречаются пряжки с трапециевидной рамкой (рис. 5: 6-7, 9) (Кравченко, 2020, рис. 204, 9-11). К числу относительно поздних предметов, по-видимому, относится и железная пряжка лировидной формы (там же, рис. 204, 5), найденная в заполнении ямы 9 помещения 14 на Сидоровском комплексе. Пряжки такого типа известны на археологическом комплексе у с. Маяки (рис. 5: 1-2) и в трупосожжениях IV этапа функционирования могильника Дюрсо (Дмитриев, 2003, с. 203, табл. 89, 59).

На Сидоровском комплексе была найдена крупная бляха, украшенная сильно стилизованным изображением трилистника (Кравченко, 2020, рис. 209, 13), и две прямоугольных бляшки со следами позолоты (Кравченко, 2020, рис. 209, 1, 11). Привлекает внимание наличие на Сидорово и Маяках бляшек от парадных конских наборов. Группа пятиугольных золоченых бляшек была подобрана на археологическом комплексе у с. Маяки (Матеріальна та духовна культура, 2017, ілл. 51). Близкая по форме бляшка была выявлена на Сидоровском комплексе (Кравченко, 2020, рис. 208, 23). В заполнении ямы, вырытой в полу помещения 16, была найдена бляшка круглой формы, покрытая золочением (Кравченко, 2020, рис. 208, 22). Близкие аналоги им имеются в конском погребении 1 Верхнесалтовского могильника (Аксенов, 2005a, рис. 2,17$)$. При всем этом крупных блях и конских налобников, близких аланским древностям Северного Кавказа (Габуев, 2005, рис. 115-116) и лесостепного Подонцовья (Аксе- 
нов, 2005 б), в среднем течении Северского Донца пока что обнаружено не было.

В целом предметы, имеющие отношение к снаряжению коня, которые происходят со среднего течения р. Северский Донец, в хронологическом плане выглядят достаточно однородно. Конские путы, аналоги которым присутствуют в материалах как степной, так и лесостепной зоны, однотипны. Форма дожила до этнографической современности. Разновидности, представленные на памятниках среднего течения Северского Донца, отличаются друг от друга способом размещения замка. Исключение составляют путы из «комплекса» 5 Государева Яра (рис. 1: 8), относящиеся к иному типу.

Оковки седел также широко распространены на памятниках салтово-маяцкой культуры. Они известны в лесостепи (Плетнева, 1989, с. 88, рис. 43; Колода, Колода, 2009, рис. 3, 10). Близкого типа оковки присутствуют в кремациях на территории Прикубанья (Дмитриев, 2003, с. 204 , рис. $91,12-13)$.

Стремена арочные с прямой или слегка выгнутой наружу подножкой средней ширины и выделенной пластинчатой петлей в верхней части. В большинстве случаев петля имеет подпрямоугольные или овальные в плане очертания. Указанные стремена близки стременам типа IA-2-3 (по классификации Е.А. Армарчук) (Армарчук, 2006, с. 15-18), Б-ІІ (по Г.А. Федорову-Давыдову) (ФедоровДавыдов, 1966, с. 14, рис. 1) или VI типу по А.Н. Кирпичникову (Кирпичников, 1973, с. 49). Их датировка у разных авторов колеблется в рамках IX-X вв. (Армарчук, 2006, с. 17).

Подавляющая часть находок удил представлена достаточно поздним в рамках хазарского времени типом. Это асимметричные, двукольчатые удила с пальчатыми псалиями и петлями для псалиев и повода, располагающимися перпендикулярно друг другу. Близ рассматриваемого нами региона удила такого типа были выявлены в Чистяковском погребении (по мнению А.В. Комара, относится к 840-880 гг.) (Тахтай, 1999, с. 166 , рис. 1, 1). В.С. Аксенов обращал внимание на то, что подобного рода удила характерны для кремаций середины - 3-й четверти IX в. (Аксенов, 2005 , с. 358). Псалии часто украшены поперечными каннелюрами. Близкого вида псалии присутствуют на удилах из кат. 126 Дмитровского могильника (Плетнева, 1989, рис. 38) и в Юго-Восточном Крыму (Майко, Гаврилов, Гукин, 2009, с. 244-245, рис. 5, 1).
Из находок удил более раннего времени следует упомянуть двусоставные двукольчатые удила, найденные на археологическом комплексе у с. Сидорово (Кравченко, 2020, рис. 204, 16). Близкие им предметы присутствуют в материалах Вознесенского комплекса (Гринченко, 1950), в захороненнях Бирского могильника (№№ 111 и 156) (Мажитов, 1968, с. $100,107-108$, табл. 28,$5 ; 29,20)$. Зафиксированы они и в погр. 4 кургана 14 Новинковского II курганного могильника на Самарской Луке, который автор публикации относила к кон. VII - 1 пол. VIII вв. (Матвеева, 1997, с. 29, $66,87$, рис. 74,$6 ; 116,2)$.

\section{Предметы вооружения}

Достаточно многочисленны и разнообразны. Абсолютное большинство их было обнаружено на крупных укреплённых поселениях. «Клады железных вещей» дают единичные находки (в основном копья). Отдельные артефакты были найдены в пределах лесных массивов. Значительная группа предметов вооружения происходит с археологического комплекса у с. Маяки. Несколько меньше их было обнаружено на археологическом комплексе у с. Сидорово. В целом они представлены всеми группами вооружения: наступательного, оборонительного и средствами индивидуальной защиты.

Детали сабель. Основная часть находок представлена перекрестиями. Одно из них, снабжённое вкладышем из бронзовой пластины, было обнаружено в 1963 г. на Маяках в подъёмном материале (Михеев, 1963, с. 5, табл. XXI, 1) (рис. 6: 1). Еще одно перекрестие сабли было найдено на памятнике в 1968 г. (Михеев, 1968, с. 4, табл. XXI, 4) (рис. 6: 2). Третье перекрестие было обнаружено в слое т. н. «Большого раскопа» неподалеку от ямы 34 (кв. 61 М) (Михеев, 1965, с. 13, табл. XXVII, 11). В 1988 г. при выборке слоя раскопа 1 на некрополе памятника был обнаружен деформированный обломок лезвия сабли (Швецов, Кравченко, 1988; Матеріальна та духовна культура, 2017, ілл. 68, 1). Перекрестие сабли, находящее аналоги в древностях IX в. (Дмитриев, 2003, с. 204, табл. 90, 39-43), было найдено на археологическом комплексе у с. Сидорово (Михеев, 1971, с. 13, табл. Х, 3 ; 1985, рис. 17 , 17; Кравченко 2020, рис. 208, $34)$.

Детали мечей немногочисленны. Тем не менее каждая из находок этих, не характерных для степной зоны, предметов, представляет существенный интерес. Одно перекрестие 
меча (рис. 6: 4) было обнаружено на площади «Большого раскопа» между погребом 47 и ямой 49. На указанном участке, вероятно, располагалось помещение, контур которого восстанавливается по скоплению в слое археологического материала (Михеев, 1966, с. 5, табл.VII, 4).

Вторая находка была подобрана в 2008 г. на поверхности городища. Она представляет собой планку от верхней части рукояти меча IX-X вв., по всей поверхности инкрустированную вертикальными полосками, выполненными при помощи жёлтой (золотой?) проволоки (рис. 6: 3) (Кравченко, Петренко, Шамрай, 2008, с. 14, рис. 27, 10, фото 40, 7; Матеріальна та духовна культура, 2017, ілл. 87).

Целый экземпляр меча $\mathrm{X}$ в. был обнаружен в 30-х гг. XX в. в ур. Плоское-Яковенково (между сёлами Пришиб и Татьяновка Славянского р-на Донецкой обл.) (Сібільов, 1950, с. 102, рис. 4, 1-4). В статье Н.В. Сибилева указано, что меч происходит из разрушенного погребения. Вместе с мечом находились стремя, бронзовая пряжка и наконечник копья (Сібільов, 1950, с. 102, рис. 4, 1-4). До Великой Отечественной войны предмет находился в музее, который во время боевых действий был разрушен. В 70-х гг. близ с. Татьяновка была найдена рукоять меча с фрагментом лезвия. Ручка имела инкрустацию серебряной проволокой (Дедов, Швецов, 1987, с. 262-263, рис. 1). Авторы публикации не связывали эту находку с мечом из Сибилёвского музея. Тем не менее, учитывая общее сходство предметов, а также место обнаружения (в дальнейшем рядом с этим местом нашли значительное количество спрятанных материалов, происходящих из Святогорского музея Н.В. Сибилёва), вполне можно предположить, что рукоять является частью меча из ур. ПлоскоеЯковенково.

Кинжалы и боевые ножи. Говоря о кинжалах, А.В. Крыганов брал за основу форму с перехватом и лезвием, обладающим повышенной прочностью и проникающей способностью. При этом, наряду с такими предметами, специально изготовленными для боевого применения, он не отрицал использование в военном деле и других ножей, отличающихся от хозяйственных размерами, толщиной и иными признаками (Крыганов, 1987, с. 82). В предлагаемой работе мы приводим описание находок ножей, пригодных для применения в военном деле. Часть их могла ранее иметь упоры на рукояти, сделанные из органических материалов, которые до наших дней не сохранились. Во избежание спорных моментов они будут характеризоваться, как боевые ножи. Представлены эти предметы небольшим количеством находок.

Несколько таких ножей было обнаружено на археологическом комплексе у с. Маяки. В яме 25 «Большого» раскопа выявлена железная полоса, которая, по мнению В.К. Михеева, представляла собой заготовку кинжала (Михеев, 1964, с. 17-18, табл. III, 23). В яме 55, которая находилась в полуземляночном помещении, раскопанном в 1966 г., были обнаружены два ножа с длинными лезвиями (Михеев, 1966, с. 16, табл. VII, 11-12). Железная обкладка ножа или кинжала (Михеев, 1964, с. 19, табл. VII, 23) и нож с долом (Михеев, 1966, c. 2, табл. XII, 13) были найдены в культурном слое «Большого» раскопа. Три предмета выявлены в подъемном материале на памятнике. Один из них нашли в 1966 г. (Михеев, 1966, с. 2, Табл. VII, 7) (рис. 6: 5). Второй предмет был найден в 1968 г. (Михеев, 1968, с. 5, табл. IX, 29) (рис. 6: 6). Еще один кинжал с обоймой, свернутой из железной пластины, был обнаружен в 1988 г. в пределах линии укреплений городища, близ склона к эскарпу (Швецов, Кравченко, 1988) (рис. 6: 11). Один кинжал, с кольцевидным завершением рукояти и длинным узким, слегка изогнутым лезвием (Голубєв, 2017, рис. 2, 3), был поднят в Государевом Яру. В лесном массиве, неподалёку от Государева Яра, была собрана группа железных предметов, среди которых находился кинжал с долом на одной стороне лезвия и упором (рис. 6: 10). Вполне вероятно, что он ранее мог иметь и металлическое перекрестие. Значительная толщина спинки и характер оформления конца, свидетельствует, что он должен был обладать значительной проникающей способностью.

На Сидоровском комплексе в заполнении рва линии укреплений был найден нож с перехватом у основания черешка и долом, который находился на одной из сторон предмета (Кравченко, 2020, рис. 202, 1). Он имел длину 19 см при длине лезвия 15 см и был типологически близок ножу с долом, найденному на Маяках.

Наконечники копий и дротиков. Составляют многочисленную категорию находок. Они присутствуют на археологическом комплексе у с. Маяки, на поселении в Государевом яру, а также в составе кладов. 
На археологическом комплексе у с. Маяки находки копий и дротиков встречены во многих расчищенных на памятнике комплекcax. Наконечник копья был обнаружен в яме 23, которую автор раскопок определил как погреб ремесленника (Михеев, 1964, с. 16-17, табл. VI, 9). «Очень массивный наконечник копья» находился в яме 26 (Михеев, 1964, с. 18, табл. VI, 10). Еще один наконечник был выявлен у восточного края ямы 39 (Михеев, 1965 , с. 16, табл. XVIII, 7). Неподалеку от ямы 43 был обнаружен еще один такой предмет (Михеев, 1965, с. 18, табл. XVIII, 8). Наконечники копий присутствовали: в составе комплекса 6 (Михеев, 1966, с. 6, табл. XVI, 5), близ ямы 55 (Михеев, 1966, с. 16, табл. XVI, 4), в яме 53 (Михеев, 1966, с. 14, табл. XIII, 10), где был обнаружен предмет, охарактеризованный В.К. Михеевым как «тесак на втулке» (Михеев, 1966, с. 12, табл. V, 12) (рис. 8: 7). Ряд наконечников выявлен при выборке культурного слоя (Михеев, 1966, с. 12, табл. XVI, 6-8; Швецов, Кравченко, 1989). Группа предметов этого типа была найдена в подъемном материале на памятнике (Михеев, 1963, c. 5-6, табл. XXI, 4-5; 1964, с. 5, табл. VI, 8; Матеріальна культура, 2017, с. 32, илл. 64, 66-67, 76) (рис. 8: 1-5, 8). Часть их хранится в материалах Славянского краеведческого музея и Святогорского историко-архитектурного заповедника.

На археологическом комплексе у с. Сидорово указанной категории материала выявлено не было. В Государевом Яру два наконечника были подобраны на поверхности памятника во время разведок. Один из них имел ромбическую в плане рабочую часть. Второй имел рабочую часть шиловидной формы (Голубєв, 2017 , с. 57 , рис. 2, 8). Кроме этого, один листовидный наконечник копья содержался в составе клада, выявленного автором в 1981 г. на селище археологического комплекса у с. Маяки (Кравченко, 2020, рис. 163).

Типологически наконечники копий и дротиков достаточно разнообразны, что было связано с их функциональным назначением. Основная часть находок представлена втульчатыми наконечниками с узким шиловидным четырехгранным пером. Они составляют большую часть находок на археологическом комплексе у с. Маяки. На интересующей нас территории и близ нее наконечники копий и дротиков указанного типа зафиксированы на поселениях Азовского побережья (Обрыв 2) и сезонных стойбищах, располагающихся в пределах Донецкого Кряжа (Великая Шишовка). А.Н. Кирпичников указывал, что копья указанного типа (пики) были связаны с вооружением всадника (Кирпичников, 1966, с. 16). Таким образом, широкое их распространение на памятниках, в пределах которых находки деталей конской сбруи представляют многочисленную категорию материала (см. выше), является вполне логичным. Показательно, что на Сидоровском комплексе, где находки стремян и удил немногочисленны, копий этого типа пока обнаружено не было.

Боевые monopbl. Часть находок происходит с археологического комплекса у с. Маяки. Боевые топоры входили в состав клада, выявленного при строительстве подстанции на берегу Северского Донца (Михеев, 1963, с. 7) (рис. 7: 1, 3). Фрагменты их были встречены в культурном слое «Большого раскопа» (Михеев, 1965, с. 8, табл. XXII, 2; 1966, с. 9, 12, табл. VII, 6) и в выявленных в нем комплексах. Они были обнаружены в ямах 34 (Михеев, 1965, с. 13, табл. XXIII, 1), 52 и 53 (Михеев, 1966, с. 14, табл. VIII, 2; X, 3). Ряд боевых топоров (рис. 7: 2, 5-8) был найден в подъемном материале как во время исследований В.К. Михеева, так и впоследствии в процессе периодических осмотров памятника (Матеріальна та духовна культура..., 2017, ілл. 69).

Целый боевой топорик (Кравченко, 2020, рис. 208, 21) найден в слое раскопа VI на Сидоровском городище (Михеев, 1971, с. 10, табл. VII, 1; 1985, с. 20 , рис. 17, 23). Кроме него на памятнике обнаружено несколько обломков лезвий топоров, назначение которых установить проблематично (Кравченко, 2020 , рис. 203, 5).

Подвесы от кистеней и булавы. Встречаются достаточно часто. Железный подвес от кистеня в виде чуть уплощенного шара со сквозным отверстием для ремня был найден в захоронении у шахты 19 в г. Чистяково (ныне г. Торез Шахтерского р-на ДНР) (Тахтай, 1999, с. 161 , табл. 1,3$)$. На археологическом комплексе у с. Сидорово близкого типа кистень находился в заполнении пом. 5, которое прилегало к внутренней линии укреплений памятника. Ещё один подвес для кистеня этого типа был найден на юго-восточной окраине городища у внутренней линии укреплений (Кравченко, 2020, рис. 208, 6). От выше описанного он отличался тем, что был изготовлен из свинца. Кроме них, на городище была поднята уплощенная железная гирька с петлей в верхней 
части (Кравченко, 2020, рис. 208, 8), которая могла являться подвесом кистеня.

Подвесы кистеней встречены на соседнем Царином городище. Ряд находок представлен в каталоге выставки (Матеріальна та духовна культура, 2017, ілл. 71; 72). В слое раскопа VI был выявлен железный стержень с петлей от кистеня (Михеев, 1968, с. 7, табл. XXI, 1) (рис. 6: 9), типологически близкий находке из Саркела (Артамонов, 1958, с. 76, рис. 55). Кроме этого, на рассматриваемом памятнике обнаружено два подвеса от кистеней с корпусом, имеющим огранку (рис. 6: $7,12)$. Один кистень имел вид плоской гирьки. От центральной её части отходит штырь, из которого была свёрнута петля (рис. 6: 8). Указанный кистень, найденный в подъемном материале, ранее был отнесён автором данной статьи к золотоордынскому времени (Кравченко, 2015, рис. 18, 6). Кроме подвесов кистеней на городище были подобраны две булавы (Матеріальна та духовна культура, 2017, ілл. 71, 1-2) (рис. 7: 4). Одну из них автор данной работы также отнёс к золотоордынскому времени (Кравченко, 2015, рис. 18, 7). Реально же подобные предметы, происходящие с памятника с полностью распаханным культурным слоем, который функционировал на протяжении всей эпохи Средневековья, датировать сложно, и они могут относиться к различным периодам его истории.

Стрелы, детали луков и колчанов. Наконечники стрел, накладки от луков, детали колчанов представлены множеством находок. Они встречены как на неукреплённых селищах, так и на степных сезонных стойбищах. Так, наконечник стрелы был найден в подъёмном материале на сезонном памятнике, расположенном у с. Глубокая Макатыха Славянского p-на Донецкой обл. Встречаются наконечники стрел в некоторых захоронениях могильников «зливкинского» типа. В захоронении 7 могильника Дроновка-3 (Лиманское озеро) было выявлено два трехлопастных наконечника стрел. Показательно, что в ногах у погребённого были положены череп и ноги жеребёнка (Татаринов, Копыл, 1981, с. 307, рис. 3, 10-11). Из разрушенных захоронений этого же некрополя происходят ещё три трехлопастных наконечника (Татаринов, Копыл, 1981 , с. 302 , рис. $3,12-14$ ).

Основная же часть находок стрел найдена на территории укрепленных поселений. Во время исследований археологического комплекса у с. Маяки В.К. Михеевым были выявлены наконечники стрел как в подъемном материале (Михеев, 1963, с. 7, табл. XXIV, 5; 1964, с. 5, табл. IV, 4-5) (рис. 9: 1-6), в культурном слое раскопов (Михеев, 1965, с. 19, табл. XXVII, 8, 10; 1966, с. 9, табл. VIII, $29 ; 1968$, c. 7 , табл.XXI, 2), так и в заполнении археологических комплексов (яма 41, комплекс 7) (Михеев, 1965, с. 16, табл. XXVII, 9; 1966, с. 6, табл. VIII, 27-28). В дальнейшем во время разведок на территории памятника был подобран еще ряд наконечников (рис. 9: 7-12). Часть их была опубликована в каталоге выставки 2017 г. (Матеріальна та духовна культура, 2017, ілл. 65).

Хорошая подборка наконечников стрел происходит и с археологического комплекса у с. Сидорово, где они были встречены как в культурном слое памятника, так и в отдельных комплексах. Практически все обнаруженные в комплексах стрелы представлены разновидностями одного типа (Кравченко, 2020, рис. $207,1-5,7)$. Это небольшие трехлопастные наконечники с черешком, отделенным от лезвия упором (Кравченко, 2020, рис. 207, 1-5, 7-9, 19-22). Подобного типа наконечники являются частой находкой на памятниках хазарского времени и были широко распространены в евразийских степях в VIII-IX вв. (Медведев, 1966, табл. 13, 9, 10, 16).

Как на Сидорово, так и на Маяках встречены детали колчанов. Среди них бронзовые и железные петли (Кравченко, 2020, рис. 206, 13), а также, застежки (Кравченко, 2020, рис. 210, 16).

При раскопках на селище, прилегающем к археологическому комплексу у с. Маяки, в 1990 г. была выявлена заготовка пластины от лука, выполненная из рога. Предмет был найден при расчистке помещения (Швецов, Кравченко, 1990). Накладки лука были обнаружены при раскопках археологического комплекса у с. Сидорово (Кравченко, 2020, рис. 201, 4-5). Они находились вместе с подвесом от кистеня на дне пом. 5. Близкого типа накладки найдены на Сухогомольшанском городище (Михеев, 1985, с. 59, рис. 30, 1).

Панцирные пластины встречены только на территории укрепленных поселений. О группе находок, обнаруженных при раскопках археологического комплекса у с. Маяки, упоминается в отчётах В.К. Михеева. По его сообщению, пластины от чешуйчатого панциря были найдены в засыпке ямы 4 (Михеев, 1964, с. 10, табл. XI, 29). Обломок панцир- 
ной пластины находился в яме 23 (Михеев, 1964, с. 17, табл. ХХ, 9). Еще один обломок панцирной пластины выявлен в яме 26 (Михеев, 1964, с. 18 , табл. XX, 10). Эти же находки упоминаются в диссертации А.В. Крыганова (Крыганов, 1987, с. 125, рис. 49, 2, 4).

Две железные пластины были найдены при раскопках археологического комплекса у с. Сидорово. Одна из них (Кравченко, 2020, рис. 208,4$)$ имеет пятиугольную форму. В её центральной части присутствует продолговатое отверстие, в которое вставлялся ремень, крепивший пластину к основе. Второй предмет представлен обломком пластины от чешуйчатого панциря (Кравченко, 2020, рис. 208, 5). На сохранившемся фрагменте по боковым сторонам и вверху имеется по два небольших отверстия. Указанная находка имеет широкий круг аналогов в древностях Центральной Азии и Южной Сибири, где панцири с пластинами такого типа широко представлены в материалах древнетюркского времени (Худяков, 1986, с. 158-159, рис. 69; 100; Худяков, 1980, с. 119-123, табл. XL). Известны они в этом регионе и на памятниках последующих эпох (Худяков, 1991, рис. $32,1-3 ; 40,11 ; 42$, 9; Бобров, Худяков, рис. 105-106).

Детали щцитов на памятниках салтовомаяцкой культуры единичны. Умбоном могла быть железная бляха, выявленная в 1911 г. в катакомбе 1 на Верхнесалтовском могильнике (Бабенко, 1914, с. 449). Одна бляха обнаружена на Битицком городище волынцевской культуры. Еще один умбон был найден в яме, относящейся к древнерусскому слою Саркела - Белой Вежи (Сорокин, 1959, с. 191, рис. $31,6 ; 33)$. Остатки кожаного щита с бронзовой оковкой выявлены на Красногоровском могильнике (Крыганов, 1989, с. 123). На стенке рогового реликвария, обнаруженного при раскопках поселения в ур. Выдылыха (близ с. Богородичное Славянского р-на Донецкой обл.), также имелось изображение воина, прикрывающегося щитом (Гриб, 2019, с. 25-26, рис. 4-5).

Все остальные находки были обнаружены при раскопках археологического комплекса у с. Сидорово. Одна бляха, выявленная в заполнении хоз. ямы 9 р. 2 (Кравченко, 2020, рис. 208,1$)$, имеет круглую выпуклую поверхность, диаметром 15,6 см при высоте 4,6 см. По ее внешнему краю идёт узкое поле, отогнутое под прямым углом. На бляху сверху при помощи заклёпок была прикреплена железная пластина, круглой в плане формы с отверстием в центре, от которой радиально отходили три полосы (Кравченко, Давыденко, 2001, с. 248-249, рис. 38,5$)$.

Вторая бляха имела несколько иной вид, что не мешает отнести ее к этой же категории материала (Кравченко, 2020, рис. 208, 3). Она была обнаружена в 2004 г. в заполнении пом. 14 (Кравченко, 2005, с. 210). Предмет имел круглую форму диаметром 11 см. От верхней, выпуклой его части отходит длинная прямая пластина с отверстием для крепления. Предмет сохранился не полностью, но сохранившаяся его часть свидетельствует, что таких пластин первоначально было не менее трёх. Таким образом, в центральной части бляхи была расположена накладная фигура, прикреплённая к ней при помощи заклёпки. Она имела три пластины, отходящие радиально от центра.

К этому же типу относилась и третья находка, выявленная на валу внутренней линии укреплений (Кравченко, 2020, рис. 208, 2). Точный диаметр этого умбона по сохранившемуся фрагменту восстановить трудно, однако, судя по всему, он имел размеры, близкие умбону из пом. 14.

Учитывая редкость и немногочисленность подобных материалов, три находки на одном памятнике представляют особый интерес. Показательно, что все известные находки умбонов были встречены на памятниках, имевших культурные напластования X в. Судя по их форме и размерам, это были умбоны от круглого или квадратного, с заокругленными углами, щита, который мог использоваться как пешим, так и конным воином (Кирпичников, 1971, с. 35). По мнению В.К. Гриба, указанные щиты распространяются в IX-X вв. среди воинов в приграничных областях Хазарского каганата под влиянием их северных соседей (Гриб, 2019, с. 26). В более позднее время умбоны с накладными пластинами, в конструкции которых проявляется связь с умбонами рассматриваемого нами типа, встречаются в материалах Верхнего Прикубанья. Один из таких предметов был обнаружен в курганном захоронении Яблоновского могильника, оставленного чёрными клобуками (Орлов, Моця, Покас, 1985, рис. $13,14)$.

Подводя итог, следует сказать, что на памятниках, расположенных в среднем течении Северского Донца, предметы вооружения и конского снаряжения являются частыми 
находками. В своё время на их многочисленность указывал В.К. Михеев. По его подсчётам, количество предметов рассматриваемой нами категории в комплексе Маяков составляет около 20\%. Их процентное соотношение, таким образом, не отличается от процента орудий, связанных с сельским хозяйством или промыслами. По мнению исследователя, «сопоставление находок оружия и конной упряжи... указывают на то, что обитатели Маяков были земледельцами-всадниками, воинами - скотоводами» (Михеев, 1968а, с. 9-10). Данный вывод вполне согласуется с наличием в рассматриваемом нами регионе группы раннесредневековых укрепленных поселений (Донецких городищ), оборонять которые без значительного воинского контингента не представлялось возможным (Кравченко, 2018). Вполне логично, что большая часть находок предметов вооружения сконцентрирована именно на этих памятниках.

Находки предметов конской сбруи встречаются намного чаще, и ареал их распространения более широкий. Они представлены на городищах, неукрепленных селищах, входят в состав «кладов железных изделий». Весьма многочисленны их находки на лесных поселениях и за их пределами, на территории лесных массивов. Предметы конского снаряжения (наряду с наконечниками стрел) иногда присутствуют и в захоронениях могильников «зливкинского» типа (Татаринов, Копыл, 1981 , с. 207, рис. 3, 10-14; Татаринов, Копыл, Шамрай, 1986 , с. 211,218 , рис. 3 ; 8). В погребении № 40 эталонного могильника «Зливки» был выявлен пояс с серебряными накладками, который может свидетельствовать о захоронении представителя воинского сословия (Швецов, 1991, с. 113, 115, рис. II; 2001; Гриб, Швецов, 2019, с. 163, рис. 3-4). В целом же предметы вооружения и конского снаряжения в могильниках «зливкинского» типа достаточно редки, что, вероятно, связано не с тем, что они представляют собой захоронения «гражданского населения», незнакомого с оружием и военным делом, а исключительно с особенностями погребального обряда этих некрополей.

\section{ЛИТЕРАТУРА}

Аксенов В.С. Комплексы конского снаряжения салтовского времени с начельниками (по материалам Верхнесалтовского катакомбного могильника) // Степи Европы в эпоху средневековья. T 4. Хазарское время / Гл.ред. А.В. Евглевский. Донецк: ДонНУ, 2005. С. 245-260.

Аксенов В.С. Новые поминальные комплексы воинов-всадников салтовского времени с территории Верхнего Подонечья // Степи Европы в эпоху средневековья. Т 4. Хазарское время / Гл.ред. А.В. Евглевский. Донецк: ДонНУ, 2005а. Т.4. С. 357-368.

Аксенов В.С., Колода В.В. Богатый вещевой комплекс близ Старой Покровки на Харьковщине // Хазарский альманах. Т.15. / Гл. ред. О.Б. Бубенок. М.: Институт славяноведения РАН, 2017. С. 37-57.

Армарчук E.A. Конская упряжь из могильников Северо-Восточного Причерноморья X-XIII вв. М.: ИА РАН, 2006. $226 \mathrm{c}$.

Артамонов М.И. Саркел - Белая Вежа // МИА. № 62 / Отв. ред. М.И. Артамонов. М.-Л.: АН СССР, 1958. C. $7-84$.

Бабенко B.A. Древние памятники Хозарской культуры в сел. Верхнем Салтове // Труды XV Apхеологического съезда в Новгороде. Т. І. М., 1914. С. 446-464.

Бартольд В.В. Введение к изданию Худуд ал- а̄лам // Сочинения. T.VIII. М.: Наука, 1973. С. 504-545.

Бобров Л.А., Худяков Ю.С. Вооружение и тактика кочевников Центральной Азии и Южной Сибири в эпоху позднего средневековья и раннего Нового времени (XV - первая половина XVIII в.). СПб.: Филологический факультет СПбГУ, 2008. 776 с.

Габуев Т.А. Аланский всадник. Сокровища князей I-XII веков. Каталог выставки. М.: Государственный музей Востока (ГМИНВ), 2005. 74 с.

Голубев А.М. Хронология салтовских памятников Верхнего Подонцовья в контексте венгерской проблематики // // III Международный мадьярский симпозиум (Будапешт, 6-10 июня 2016 г.) / Ред. А. Тюрк, А.С. Зеленков. Будапешт: 2018. С. 367-402.

Голубєв А.М. Салтово-маяцький кремаційний могильник «Государів Яр» у Середньому Подонців'ї. // Археологія. 2017. №2. С. 57-64.

Гриб В.К. Щит, как элемент защитного вооружения у населения Салтово-Маяцкой культуры // Вестник Донецкого национального университета. Серия Б. Гуманитарные науки. 2019. №3. С. 23-28. 
Гриб В.К., Швецов М.Л. Серебряный пояс из погребения 40 могильника Зливки // Археология как жизнь. Памяти Евгения Павловича Мыськова / Под ред. Е.В. Круглова, А.С. Лапшина, И.Ю. Лапшиной. Волгоград: Сфера, 2019. С. 158-173.

Грінченко В.А. Памятка VIII ст. коло с. Вознесенки на Запоріжжі // Археологія. Т.ІІІ. К.: Вид. АН УССР, 1950. С. 37-63.

Давыденко В.В., Гаврилова А.Н. Новый комплекс раннего средневековья «Государев Яр» в Святогорье // Святогірський альманах 2011. / Ред.-упоряд. В.М. Дєдов. Донецк: Вид. «Донбас», ТОВ «РА Ваш імідж», 2011. С. 20-31.

Давыденко В.В., Гриб В.К. «Государев Яр» - новый памятник Х-ХІ вв. в среднем течении Северского Донца (предварительная публикация) // Археологический альманах. № 25 / Гл. ред. А.В. Колесник. Донецк: Бытсервис, 2011. С. 25-269.

Дедов В.Н., Швецов М.Л. Находка древнерусского меча в Донбассе // СА. 1987. №1 . С. 262-263.

Дмитриев А.В. Могильник Дюрсо - эталонный памятник древностей IV-IX вв. // Крым, СевероВосточное Причерноморье и Закавказье в эпоху средневековья IV-XIII вв. / Отв. ред. Т.И. Макарова, С.А. Плетнева. М.: Наука, 2003. С. 200-206.

Дьячков C.B. Х научная конференция-презентация «Проблемы исследования и охраны историкокультурного наследия Украины» Итоги полевых исследований в 2015 году // Древности. 2016. Вып. 14. C. 222-225.

Кирпичников А.Н. Древнерусское оружие. Копья, сулицы, боевые топоры, булавы, кистени. IX-XIII вв. Вып. ІІ / САИ. Вып. Е1-36. М.-Л.: Наука, 1966. 181 с.

Кирпичников А.Н. Снаряжение всадника и верхового коня на Руси IX-XIII вв. / САИ. Вып. Е-1-36. Л.: Наука, 1973. 140 с.

Колода В.В. Два салтовских комплекса из Государева Яра // Салтово-маяцька археологічна культура: проблеми та дослідження. Вип. 3 / Отв. ред. О.О. Савчук. Харків: ОКЗ «ХНМЦОКС», 2013. С. 73-81.

Колода В.В. О хозяйственных со стандартизированными наборами предметов на салтовских поселениях // Проблемы истории и археологии Украины. Материалы IX международной научной конференции / Отв. ред. С.В. Дьячков Харьков, 2014. С. 54-55.

Колода В.В., Колода T.A. Кузнечная мастерская нового ремесленного центра лесостепной Хазарии // Хазарский альманах. Т. 8 / Гл. ред. Н.Н. Олейник. Киев-Харьков: Изд-во Международного Соломонового университета, 2009. С. 203-215.

Комар А.В., Сухобоков О.В. Вооружение и военное дело Хазарского каганата // Восточноевропейский археологический журнал. 2000. № 2(3), март-апрель. Доступно по URL: http://archaeology.kiev.ua/ journal/020300/komar_sukhobokov.htm (дата обращения: 04.12.2020)

Кравченко Э.Е. Городища среднего течения Северского Донца // Хазарский альманах. № 3 / Гл. ред. В.К. Михеев. Киев-Харьков: Изд-во Международного Соломонового университета, 2004. С. 242-276.

Кравченко Э.Е. Исследование хозяйственного объекта на археологическом комплексе у с. Сидорово в среднем течении Северского Донца // Проблеми збереження і використання культурної спадщини в Україні. Слов'янськ: Печатный двор, 2005. С. 208-222.

Кравченко Э.Е. Памятники золотоордынского времени в степях между Днепром и Доном // Генуэзская Газария и Золотая Орда / Отв. ред. С.Г. Бочаров, А.Г. Ситдиков. Кишинёв: Stratum plus, 2015. С. 407-474.

Кравченко Э.Е. Оборонительные сооружения археологического комплекса у с. Сидорово // Поволжская археология. 2018. № 2(24). С. 10-32.

Кравченко Э.Е. Сидоровский археологический комплекс на р. Северский Донец / Археология Евразийских степей. 2020. №4. 344 с.

Кравченко Э.Е., Давыденко В.В. Сидоровское городище // Степи Европы в эпоху средневековья. Т. 2 / Гл. ред. А.В. Евглевский. Донецк: Изд-во ДонНУ, 2001. С. 233-302.

Кравченко Э.Е. Петренко А.Н., Шамрай А.В. Отчет об исследованиях на археологическом комплексе Маяки в 2008 году // НА ИА НАНУ №2008/82.

Кравченко Э.Е., Шамрай А.В. О группе комплексов с Царина городища (среднее течение Северского Донца) // Проблеми збереження і використання культурної спадщини в Україні. Матеріали II Всеукраїнської науково-практичної конференції, присвяченої 10-й річниці надання Святогірському Успенському монастиреві статусу Лаври (2004), 170-річчю відновлення Святогірського Успенського монастиря (1844), 80-річчю створення краєзнавчого музею М.В.Сібільовим у Святогірську (1934). 
25-26 вересня 2014 року м. Святогірськ. Донецьк: ТОВ «Східний видавничий дім», Ваш імідж, 2014. C. $183-192$.

Красильников К.И. Этнокультурные признаки населения степей Хазарской периферии (к вопросу об идентификации) // Научные труды по иудаике. Материалы XVII Международной ежегодной конференции по иудаике. Т. II / Отв. ред. В.В. Мочалова. М.: Пробел-2000, 2010. С. 16-32.

Крыганов А.B. Вооружение и конское снаряжение кочевников юга Восточной Европы VII-X вв. Дисс. ... канд. истор. наук. Харьков: Харьковский Государственный университет. 1987 //НА ИА НАНУ Ф. 12 ; № 656 .

Локтюшев С.А. Научно-ценные ранне-исторические памятники, выявленные археологическими раскопками в Ворошиловградской области // Краєзнавчі записки. 2009. Вип. V. С. 299-300.

Мажитов Н.А. Бахмутинская культура. Этническая история населения Северной Башкирии середины I тысячелетия нашей эры. М.: Наука, 1968. 161 с.

Майко В.В., Гаврилов А.В., Гукин В.Д. Комплекс оружия, конского снаряжения и бытовых предметов с праболгарского поселения IX - 1-й пол. X вв. в Юго-Восточном Крыму // Хазарский альманах. Т. 8 / Гл. ред. Н.Н. Олейник. Киев-Харьков: Изд-во Международного Соломонового университета, 2009. С. 237-263.

Матвеева Г.И. Могильники ранних болгар на Самарской Луке. Самара: Самарский университет, 1997. $226 \mathrm{c}$.

Матеріальна та духовна культура населення Подінців'я в період середньовіччя VIII-XIV ст. на прикладі городища «Царине» (Маяцьке). Каталог виставки / Автори укладачі Дєдов В.Н., Шамрай А.В., Соловкін О.О. Київ: Вид. САМ. 2017. 95 с.

Медведев А.Ф. Ручное метательное оружие. Лук и стрелы. Самострел / САИ. Вып. Е1-36. М.: Наука. 1966. $154 \mathrm{c}$.

Михеев B.K. К итогам исследований поселения салтово-маяцкой культуры у с.Маяки. Рукопись. 1968 a. $11 \mathrm{c}$.

Михеев В.К. Отчет о работе средневековой археологической экспедиции ХГУ им. А.М. Горького в 1971 г. // НА ИА НАНУ № 1971/76.

Михеев B.К. Отчет о раскопках поселения и могильника салтовской культуры у с. Маяки летом 1965 г. //НА ИА НАНУ №1965/18.

Михеев B.К. Отчет об археологических исследованиях поселения салтово-маяцкой культуры у с. Маяки в 1968 г. // Архив ИА НАНУ 1968/48.

Михеев В.К. Отчет об археологических раскопках поселения у с. Маяки в 1964 г. // НА ИА НАНУ №1964/28

Михеев В.К. Отчет об археологических раскопках у с. Маяки Славянского р-на Донецкой обл. // НА ИА НАНУ $1966 / 80$.

Михеев В.К. Подонье в составе Хазарского каганата. Харьков, 1985. 148 с.

Михеев B.K. Результаты археологических работ на Маяцком городище в 1963 г. // Архив музея истории и этнографии Слободской Украины Харьковского национального университета. Ф. 1; Оп. 2; Ед. хр. 4.

Орлов Р.С., Мочя А.П., Покас П.М. Исследования летописного Юрьева на Росси и его окрестностей // Земли Южной Руси IX-XIV вв. / Под ред. П.П. Толочко. К.: Наукова думка, 1985. С. 41-60.

Плетнева С.А. От кочевий к городам / МИА. № 142. М.: Наука, 1967. 198 с.

Плетнева С.А. На славяно-хазарском пограничье. Дмитриевский археологический комплекс. М.: Наука, 1989. 288 с.

Плетнева С.А. Очерки хазарской археологии. М.; Иерусалим: Гешарим / Мосты культуры, 1999. $280 \mathrm{c}$.

Сібільов М.В. Археологічні пам'ятки на Дінці у зв'язку з походами Володимира Мономаха та Ігоря Новгород Сіверського // Археологія, Вип. IV. К.: Вид. АН УССР, 1950. С. 99-114.

Сорокин С.С. Железные изделия Саркела-Белой Вежи // МИА. № 75 / Отв. ред. М.И. Артамонов. М.-Л.: Изд-во АН СССР, 1959. С. 148-150.

Татаринов С.И., Копыл А.Г. Дроновские древнеболгарские могильники на р. Северский Донец // CA. 1981. №1. С. 300-307.

Татаринов С.И., Копьлл А.Г., Шамрай А.В. Два праболгарских могильника на Северском Донце // CA. 1986. №1. С. 209-221. 
Taxmaй A.K. Погребальный комплекс хазарского времени из округи г. Чистяково Сталинской области // Vita antiqua. 1999. №2. С. 160-169.

Федоров-Давыдов Г.А. Кочевники Восточной Европы под властью золотоордынских ханов. Археологические памятники. М.: Изд-во МГУ, 1966. 276 с.

Ходжайов Т.К., Швецов М.Л., Ходжайова Г.К., Фризен С.Ю. Население Подонцовья эпохи Золотой Орды (по материалам могильников у с. Маяки) // Степи Европы в эпоху средневековья. Т. 11. Золотоордынское время. / Гл. ред. А.В. Евглевский.. Донецк: ДНУ, 2012.С. 125-192.

Худяков Ю.С. Вооружение енисейских кыргызов. Новосибирск: Наука, 1980. 176 с.

Худяков Ю.С. Вооружение средневековых кочевников Южной Сибири и Центральной Азии. Новосибирск: Наука, 1986. 269 с.

Худяков Ю.С. Вооружение центральноазиатских кочевников в эпоху раннего и развитого средневековья. Новосибирск: Наука, 1991. 190 с.

Швецов М.Л. Могильник Зливки // Проблеми на прабългарската история и култура. Т.2. София: Аргес, 1991. С. 109-123.

Швецов М.Л. Погребение 40 могильника Зливки // Проблемы истории и археологии Украины. Материалы международной научной конференции / Отв. ред. С.Б. Сорочан. Харьков: ХНУ, 2001. С. 110-111.

Швецов М.Л., Кравченко Э. Е. Отчет об археологических исследованиях экспедиции в 1988 г. // НА ИА НАНУ $1988 / 165$.

Швецов М.Л., Кравченко Э.Е. Отчет о спасательных археологических исследованиях на памятнике у с. Маяки и пос. Донецкого Славянского р-на Донецкой обл. в 1989 г. //НА ИА НАНУ №1989/249. 22 с.

\section{Информация об авторе}

Кравченко Эдуард Евгеньевич, старший научный сотрудник, Донецкий Республиканский краеведческий музей (г. Донецк, Украина); sidae@mail.ru

\section{REFERENCES}

Aksenov, V. S. 2005. In Evglevskii, A. V. (ed.-in-chief). Stepi Evropy v epokhu srednevekov'ia (Steppes of Europe in the Middle Ages) 4. Khazarskoe vremia (Khazar Time). Donetsk: Donetsk National University, 245-260 (in Russian).

Aksenov, V. S. 2005. In Evglevskii, A. V. (ed.-in-chief). Stepi Evropy v epokhu srednevekov'ia (Steppes of Europe in the Middle Ages) 4. Khazarskoe vremia (Khazar Time). Donetsk: Donetsk National University, 357-368 (in Russian).

Aksenov, V. S. 2017. In Bubenok, O. B. (ed.). Khazarskii al'manakh (Khazar Almanac) 15. Moscow: Instutite for Slavic Studies, Russian Academy of Sciences, 37-57 (in Russian).

Armarchuk, E. A. 2006. Konskaia upriazh' iz mogil'nikov Severo-Vostochnogo Prichernomor'ia X-XIII vv. (Horse Harness from the Burial Mounds of the North-Eastern Black Sea Region dated the 10th-13th cc.). Moscow: Institute of Archaeology, Russian Academy of Sciences (in Russian).

Artamonov, M. I. 1958. In Artamonov, M. I. (ed.). Materialy i issledovaniia po arkheologii SSSR (Materials and Research in the USSR Archaeology) 62. Moscow; Leningrad: the USSR Academy of Sciences, 239-268 (in Russian).

Babenko, V. A. 1914. Trudy XV Arkheologicheskogo s"ezda v Novgorode (Proceedings of the 15th Archaeological Congress in Novgorod) I. Moscow: "Sinodal'naia tipografiia" Publ., 446-464(in Russian)..

Bartol'd, V. V. 1973. In Sochineniia (Works) 8. Moscow: "Nauka” Publ., 504-545 (in Russian).

Bobrov, L. A., Khudyakov, Yu. S. 2008. Vooruzhenie i taktika kochevnikov Tsentral'noy Azii i Yuzhnoy Sibiri $v$ epokhu pozdnego srednevekov'ya i rannego Novogo vremeni (XV-pervaya polovina XVIII v.). (Armament and Tactics of the Central Asian and South Siberian Nomads in the Late Middle Ages and the Early Modern Time (15th - first half of 18th cc.). Saint Petersburg: Faculty of Filology, Saint Petersburg State University (in Russian).

Gabuev, T. A. 2005. Alanskii vsadnik. Sokrovishcha kniazei I-XII vekov. Katalog vystavki. (The Alan Horseman. Treasures of 1st-12th century Princes. Exhibition Catalogue). Moscow: The State Museum of Oriental Art (in Russian).

Golubev, A. M. 2018. In Tyurk, A., Zelenkov, A. S. (eds.). III Mezhdunarodniy mad'yarskiy simpozium (Budapesht, 6-10 iyunya 2016 g.) (3rd International Magyar Symposium (Budapest, June 6-10, 2016)). Budapesht. 367-402 (in Russian).

Golubev, A. M. 2017. In Arkheologiia (Archaeology) 2, 57-64 (in Ukrainian). 
Grib, V. K. 2019. In Vestnik Donetsskogo natsional'nogo universiteta. Seriia B: Gumanitarnye nauki (Bulletin of the of Donetsk National University. Series B: Humanities") (3), 23-28 (in Russian).

Grib, V. K., Shvetsov, M. L. 2019. In Kruglov, E. V., Lapshin, A. S., Lapshin, I. Yu. (eds.). Arheologiia kak zhizn'. Pamiati Evgeniia Pavlovicha Mys'kova (Archaeology as Life. In Memory of Evgeny Pavlovich Myskov). Volgograd: "Sfera" Publ., 158-173 (in Russian).

Grincheko, V. A., 1950. In Arkheologiia (Archaeology) 3, 37-63 (Ukrainian).

Davydenko, V. V., Gavrilova, A. N. 2011. In Dedov, V. M. (ed.). Sviatogirs 'kkii al'manakh (Svyatogirsky Almanac). Donetsk, 20-31 (in Russian).

Davydenko, V. V., Grib, V. K.. 2011. In Kolesnik, A. V. (ed.). Arkheologicheskii al'manakh (Archaeological almanac) 25. Donetsk: "Bytservis" Publ., 25-269 (in Russian).

Dedov, V. N., Shvetsov, M. L. 1987. In Sovetskaia Arkheologiia (Soviet Archaeology) (1), 262-263 (in Russian).

Dmitriev, A. V. 2003. In Makarova, T. I., Pletneva, S. A. (eds.). Krym, Severo-Vostochnoe Prichernomor'e $i$ Zakavkaz'e v epokhu srednevekovija IV-XIII vv. (Crimea, North-Eastern Black Sea region and Transcaucasia in the Middle Ages in the 4th-13th cc.). Moscow: "Nauka" Publ., 200-206 (in Russian).

D’yachkov, S. V. 2016. In Drevnosti (Antiqquities) 14, 222-225 (in Russian).

Kirpichnikov, A. N. 1966. Drevnerusskoe oruzhie (Early Russian Weapons) 2. Kop'ia, sulitsy, boevye topory, bulavy, kisteni IX-XIII vv. (Spears, Lances, War Axes, Maces, Flails of 9th-13th Centuries). Series: Svod Arkheologicheskikh Istochnikov (Corpus of Archaeological Sources) E1-36. Moscow; Leningrad: "Nauka" Publ. (in Russian).

Kirpichnikov, A. N. 1973. Snariazhenie vsadnika i verkhovogo konia na Rusi IX-XIII vv. (Munitions of Rider and Riding Horse in Rus' of 9th - 13th Centuries). Series: Corpus of Archaeological Sources E1-36. Leningrad: "Nauka" Publ. (in Russian).

Koloda, V. V. 2013. In Saltovo-maiats'ka arkheologichna kul'tura: problemi ta doslidzhennia (SaltovoMayaki Archaeological Culture: Issues and Achievements) 3. Kharkiv: "KhNMTsOKS" Publ., 73-81(in Russian).

Koloda, V. V. 2014. In Dyachkov, S. V. (ed.). Problemy istorii i arkheologii Ukrainy (Issues of History and Archaelogy of Ukraine). Kharkiv: Kharkiv National University, 54-55 (in Russian).

Koloda, V. V., Koloda, T. A. 2009. In Oleynik, N. N. (ed.). Khazarskii al'manakh (Khazar Almanac) 8. Kharkiv: "International Solomon University" Publ., 203-215 (in Russian).

Komar, A. V., Sukhobokov, O. V. 2000. In Vostochoevropeiskii arkheologicheskii zhurnal (East-European Archaeological Journal) 3(2), March-April Available at: http://archaeology.kiev.ua/journal/020300/komar_ sukhobokov.htm (Accessed: 04.12.2020).

Kravchenko, E. E. 2004. In Mikheev, V. K. (ed.). Khazarskii al'manakh (Khazar Almanac) 3. KievKharkiv: "International Solomon University" Publ., 242-276 (in Russian).

Kravchenko, E. E. 2005. In Problemy zberezhennia i vikoristannia kul 'turnoi spadshchini v Ukraini (Issues of the Preservation and Use of Cultural Heritage in Ukraine). Slovyansk: "Pechatnyi dvor" Publ., 208-222 (in Russian).

Kravchenko, E. E. 2018. In Povolzhskaya arkheologiya (Volga River Region Archaeology) 24 (2), 10-32 (in Russian).

Kravchenko, E. E. 2015. In Bocharov, S. G., Sitdikov, A. G. (eds.). Genuezskaia Gazariia i Zolotaia Orda (The Genoese Gazaria and the Golden Horde). Kazan; Simferopol; Kishinev: "Stratum Plus" Publ., 407-474 (in Russian).

Kravchenko, E. E., Petrenko, A. N., Shamrai, A. V. 2008. Otchet ob issledovaniiakh na arkheologicheskom komplekse Mayaki v 2008 godu (Report on Studes at the Mayaki Archaeological Complex in 2008). Research Archive of the Institute of Archaeology of the National Academy of Sciences of Ukraine. No. 2008/82 (in Russian).

Kravchenko, E. E. 2020. Sidorovskii arkheologicheskii kompleks na r. Severskii Donets (Sidorovsky Archaeological Complex on the Seversky Donets River) Arkheologiia Evraziiskikh stepei (Archaeology of Eurasian Steppes) 4 (in Russian).

Kravchenko, E. E., Davydenko, V. V. 2001. In Evglevskii, A. V. (ed.-in-chief). Stepi Evropy v epokhu srednevekov'ia (Steppes of Europe in the Middle Ages) 2. Khazarskoe vremia (Khazar Time). Donetsk: Donetsk National University, 233-302 (in Russian). 
Kravchenko, E. E., Shamrai, A. V. 2014. In Problemy zberezhennia i vikoristannia kul turnoi spadshchini v Ukraini (Issues of the Preservation and Use of Cultural Heritage in Ukraine). Donetsk: "Vash imidzh" Publ., 183-192 (in Russian).

Krasil'nikov, K. I. 2010. In Mochalova, V. V. (ed.). Nauchnye trudy po iudaike. Materialy XVII Mezhdunarodnoi ezhegodnoi konferentsii po iudaike (Scientific Works on Jewish Studies. Materials of the 17th Annual International Conference on Jewish Studies) II. Moscow: "Probel-2000" Publ., 16-32 (in Russian).

Kryganov, A. V. 1987. Vooruzheniie i konskoe snariazhenie kochevnikoviuga Vostochnoi Evropy (Armament and Horse Equipment of the Nomads of the South of Eastern Europe in the 7th-10th cc.). Diss. of Candidate Historical Sciences. Research Archive of the Institute of Archaeology of the National Academy of Sciences of Ukraine. Fund 12, No. 656 (in Russian).

Loktyushev, S. A. 2009. In Kraeznavchi zapiski (Local History Notes) 5, 299-300 (in Russian).

Mazhitov, N. A. 1968. Bakhmutinskaia kul'tura: Etnicheskaia istoriia naseleniia Severnoi Bashkirii serediny I tysiacheletiia nashei ery (The Bakhmutino Culture: Ethnic History of the Northern Bashkiria Population in the Middle I Millennium AD). Moscow: "Nauka" Publ. (in Russian).

Maiko, V. V., Gavrilov, A. V., Gukin, V. D.. 2009. In Oleynik, N. N. (ed.). Khazarskii al'manakh (Khazar Almanac) 8. Kharkiv: "International Solomon University" Publ., 237-263 (in Russian).

Matveeva, G. I. 1997. Mogil'nik rannikh bulgar na Samarskoi Luke (Могильники ранних болгар на Самарской Луке). Samara: Samara State University (in Russian).

Matveeva, G. I. 1997. Mogil'nik rannikh bulgar na Samarskoi Luke (Burial grounds of the Early Bolgars on Samarskaya Luka). Samara: Samara State University (in Russian).

Dedov, V. N., Shamray, A. V., Solovkin, O. O. (comp.). 2017. Material'na ta dukhovna kul'tura naseleniia Podintsiv'ia v period seredn'ovchchia VIII-XIV st. na prikladi gorodishcha "Tsarine" (Maiats'ke) (The Material and Spiritual Culture of the Population of the Don Region in the Period of the Mid-8thI-14th cc. at the Example of "Tsarina" Fortified Settlement (Mayaki)). Kiev: "SAM" Publ. (in Ukrainian).

Medvedev, A. F. 1966. Ruchnoe metatel'noe oruzhie (luk i strely, samostrel) VIII-XIV vv. (Hand Missile Weapons (Bow and Arrows, Crossbow) of 8th - 14th Centuries). Svod Arkheologicheskikh Istochnikov (Corpus of Archaeological Sources) E1-36. Moscow: "Nauka" Publ. (in Russian).

Mikheev, V. K. 1963. Rezul 'taty arkheologicheskikh rabot na Maiatskom gorodishche v $1963 \mathrm{~g}$. (Results of Archaeological Activities at Mayaki Settlement in 1963). Archive of the Museum of History and Ethnography of Sloboda Ukraine, Kharkiv National University. Fund 1. Inv. 2. Unit 4 (in Russian).

Mikheev, V. K. 1964. Otchet o arkheologicheskikh raskopkhakh poseleniia u sela Maiaki v1964 g. (Report on Archaeological Excavations at a Settlement near Mayaki Village in 1964). Research Archive of the Institute of Archaeology of the National Academy of Sciences of Ukraine. No. 1964/28 (in Russian).

Mikheev, V. K. 1965. Otchet o raskopkakh poseleniia i mogil'nika saltovskoi kul'tury u sela Maiaki letom 1965 g. (Report on the Excavations of a Settlement and Burial Ground of the Saltovo Culture near Mayaki Village in the Summer of 1965.). Research Archive of the Institute of Archaeology of the National Academy of Sciences of Ukraine. No. 1965/18 (in Russian).

Mikheev, V. K. 1966. Otchet o arkheologicheskikh raskopkakh poseleniia u sela Maiaki Slaviankogo raiona Donetskoi oblasti. (Report on Archaeological Excavations near Mayaki Village of the Slavyansky District of the Donetsk Region.). Research Archive of the Institute of Archaeology of the National Academy of Sciences of Ukraine. No. 1966/80 (in Russian).

Mikheev, V. K. 1968. Kitogam issledovanii poseleniia saltovo-maiatskoi kul'tury (The Results of the Study of a Settlement of the Saltovo-Mayaki Culture near Mayaki Village) (in Russian).

Mikheev, V. K. 1968. Otchet ob arkheologicheskikh issledovaniiakh poseleniia saltovskoi kul'tury u sela Maiaki v 1968 g. (Report on the Excavations of a Settlement and Burial Ground of the Saltovo Culture near Mayaki Village in the Summer of 1965.). Research Archive of the Institute of Archaeology of the National Academy of Sciences of Ukraine. No. 1968/48 (in Russian).

Mikheev, V. K. 1971. Otchet o rabote srednevekovoi arkheologicheskoi ekspeditsii Khar'kovskogo gosudarstvennogo universiteta. A.M. Gor'kogo v 1971 g. (Report on the Activities work of the Medieval Archaeological Expedition of the National University of Kharkov named after A.M. Gorky in 1971). Research Archive of the Institute of Archeology of the National Academy of Sciences of Ukraine. No. 1971/76 (in Russian).

Mikheev, V. K. 1985. Podon'e v sostave Khazarskogo kaganata (The Don Region in Khazar Khaganate). Kharkiv (in Russian). 
Orlov, R. S., Motsya, A. P., Pokas, P. M. 1985. In Tolochko, P. P. (ed.). Zemli Yuzhnoi Rusi IX-XIV vv. (Southern Russian Lands in the 9th-14th cc.). Kiev: "Naukova dumka" Publ., 41-60 (in Russian).

Pletneva, S. A. 1989. Na slaviano-khazarskom pogranich'e. Dmitrievskii arkheologicheskii kompleks (In the Slavic-Khazar Borderlands. Dmitriev Archaeological Complex). Moscow: "Nauka" Publ. (in Russian).

Pletneva, S. A. 1967. Ot kochevii k gorodam. Saltovo-maiatskaia kul'tura (From Camps to Towns. Saltovo-Mayaki Culture). Materialy i issledovaniia po arkheologii (Proceedings and Research in Archaeology of the USSR) 142. Moscow: "Nauka" Publ. (in Russian).

Pletneva, S. A. 1999. Ocherki khazarskoi arkheologii (Essays on Khazar Archaeology). Moscow; Jerusalem: "Gesharim"; "Mosty kul'tury" Publ. (in Russian).

Sibil'ov, M. V. 1950. In Arkheologiia 4, 99-114 (in Ukrainian).

Sorokin, S. S. 1959. In Artamonov, M. I. (ed.). Materialy i issledovaniia po arkheologii SSSR (Materials and Research in the USSR Archaeology) 75. Moscow; Leningrad: the USSR Academy of Sciences, 148-150 (in Russian).

Tatarinov, S. I., Kopyl, A. G. 1981. In Sovetskaia Arkheologiia (Soviet Archaeology) (1), 300-307 (in Russian).

Tatarinov, S. I., Kopyl, A. G., Shamray, A. V. 1981. In Sovetskaia Arkheologiia (Soviet Archaeology) (1), 209-221 (in Russian).

Takhtay, A. K. 1999. In Vita antiqua (2), 160-169 (in Russian).

Fedorov-Davydov, G. A. 1966. Kochevniki Vostochnoi Evropy pod vlast'iu zolotoordynskikh khanov: Arkheologicheskie pamiatniki (East-European Nomads under the Golden Horde's Khans: Archaeological Sites). Moscow: Moscow State University (in Russian).

Khodzhayov, T. K., Shvetsov, M. L., Khodzhayova, G. K., Frizen, S. Yu. 2012. In Evglevskii, A. V. (ed.-in-chief). Stepi Evropy v epokhu srednevekov'ia (Steppes of Europe in the Middle Ages) 11. Donetsk: Donetsk National University, 125-192 (in Russian).

Khudyakov, Yu. S. 1980. Vooruzhenie eniseiskikh kyrgyzov (Armament of the Yenisei Kyrgyz). Novosibirsk: "Nauka" Publ. (in Russian).

Khudiakov, Yu. S. 1986. Vooruzhenie srednevekovykh kochevnikov Iuzhnoi Sibiri i Tsentral'noi Azii (Arms of the Medieval Nomads of the Sourthern Siberia and Central Asia). Novosibirsk: "Nauka" Publ. (in Russian).

Khudyakov, Yu. S. 1991. Vooruzhenie tsentral'noaziatskikh kochevnikov v epokhu rannego i razvitogo srednevekov'ya (Armament of Central Asian Nomads in the Early and Developed Middle Ages). Novosibirsk: "Nauka" Publ. (in Russian).

Shvetsov, M. L. 1991. In Problemi na prablgarskata i kultura (Issues of the Proto-Bolgar History and Culture) 2. Sofia: "Agres" Publ., 109-123 (in Russian).

Shvetsov, M. L. 2001. In Sorochan, S. B. (ed.). Problemy istorii i arkheologii Ukrainy (Issues of History and Archaelogy of Ukraine). Kharkiv: Kharkiv National University, 110-111 (in Russian).

Shvetsov, M. L., Kravchenko, E. E. 1988. Otchet ob arkheologicheskikh issledovaniiakh ekspeditsii v 1988 g. (Report on the Archaeological Studies of the Expedition in 1988). Research Archive of the Institute of Archaeology of the National Academy of Sciences of Ukraine. No. 1988/165 (in Russian).

Shvetsov, M. L., Kravchenko, E. E. 1989. Otchet o spasate'nykh arkheologicheskikh issledovaniiakh na pamiatnike u sela Maiaki Slaviankogo raiona Donetskoi oblasti v 1989 g. (Report on Rescue Archaeological Studies at the Monument near Mayaki and Donetsky villages in Slavyansky District of Donetsk Region in 1989.). Research Archive of the Institute of Archeology of the National Academy of Sciences of Ukraine. No. 1989/249. (in Russian).

\section{About the Author:}

Kravchenko Eduard E. Donetsk Museum of Local History. Chelyuskintsev 189-a, Donetsk, 283048,Ukraine; sidae@mail.ru

Статья поступила в журнал 01.08.2020 г. Статья принята к публикации 01.09.2020 г. 


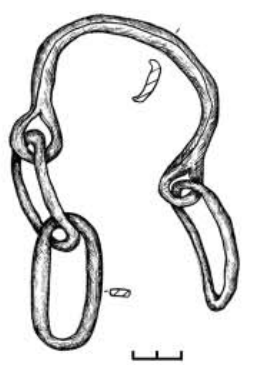

1

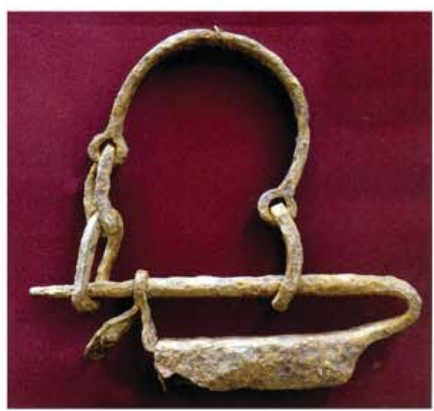

2
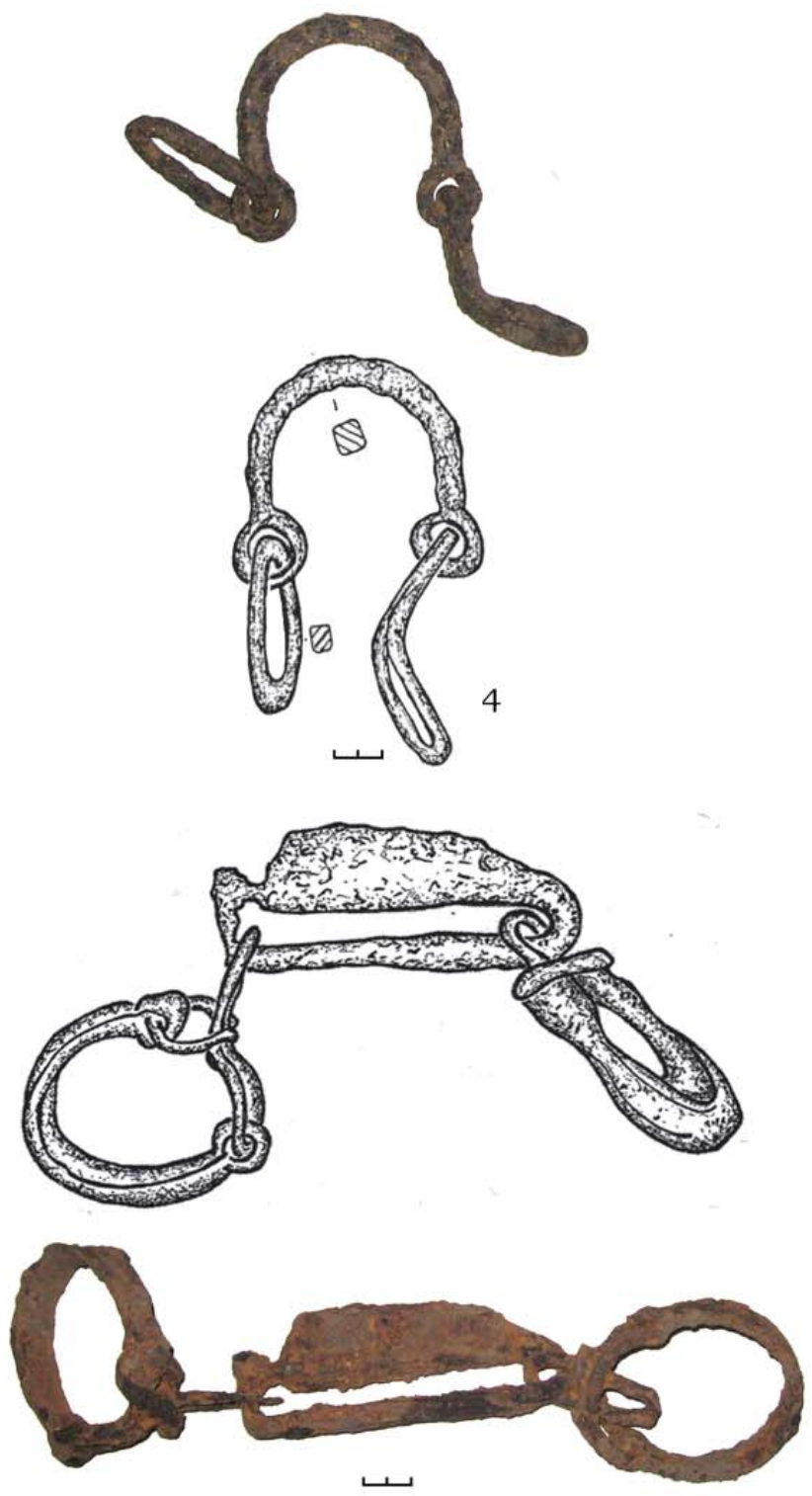

8

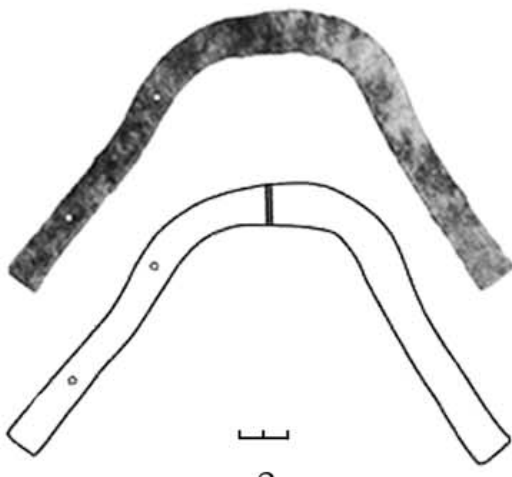

3
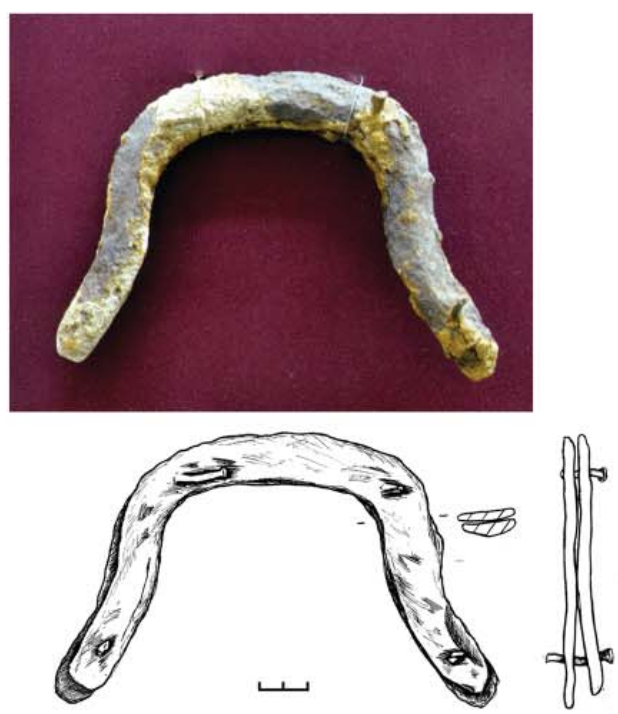

5
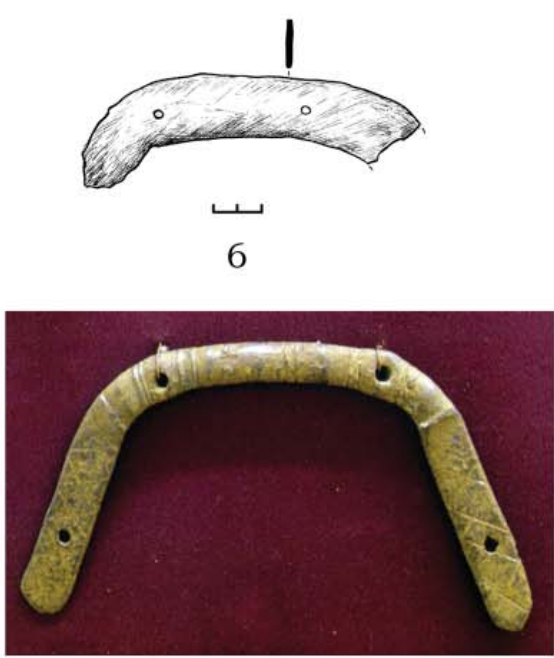

7

Рис. 1. Конские путы и детали седел с памятников в среднем течении Северского Донца: 1-2, 5-7 - Маяки; 3-4, 8 - Государев Яр. (2, 5, 7 - по Матеріальна та духовна культура, 2017, Ілл. 59, 62; 4, 8 - по Давыденко, Гриб, 2011; 3 - по Колода, 2013).

Fig. 1. Hobble and saddle details from the sites located in the middle reaches of the Seversky Donets: 1-2, 5-7 - Mayaki; 3-4, 8- Gosudarev Yar. (2, 5, 7 - after Material and Spiritual Culture, 2017, Ill. 59, 62; 4, 8 - after Davydenko, Grib, 2011; 3 - after Koloda, 2013). 


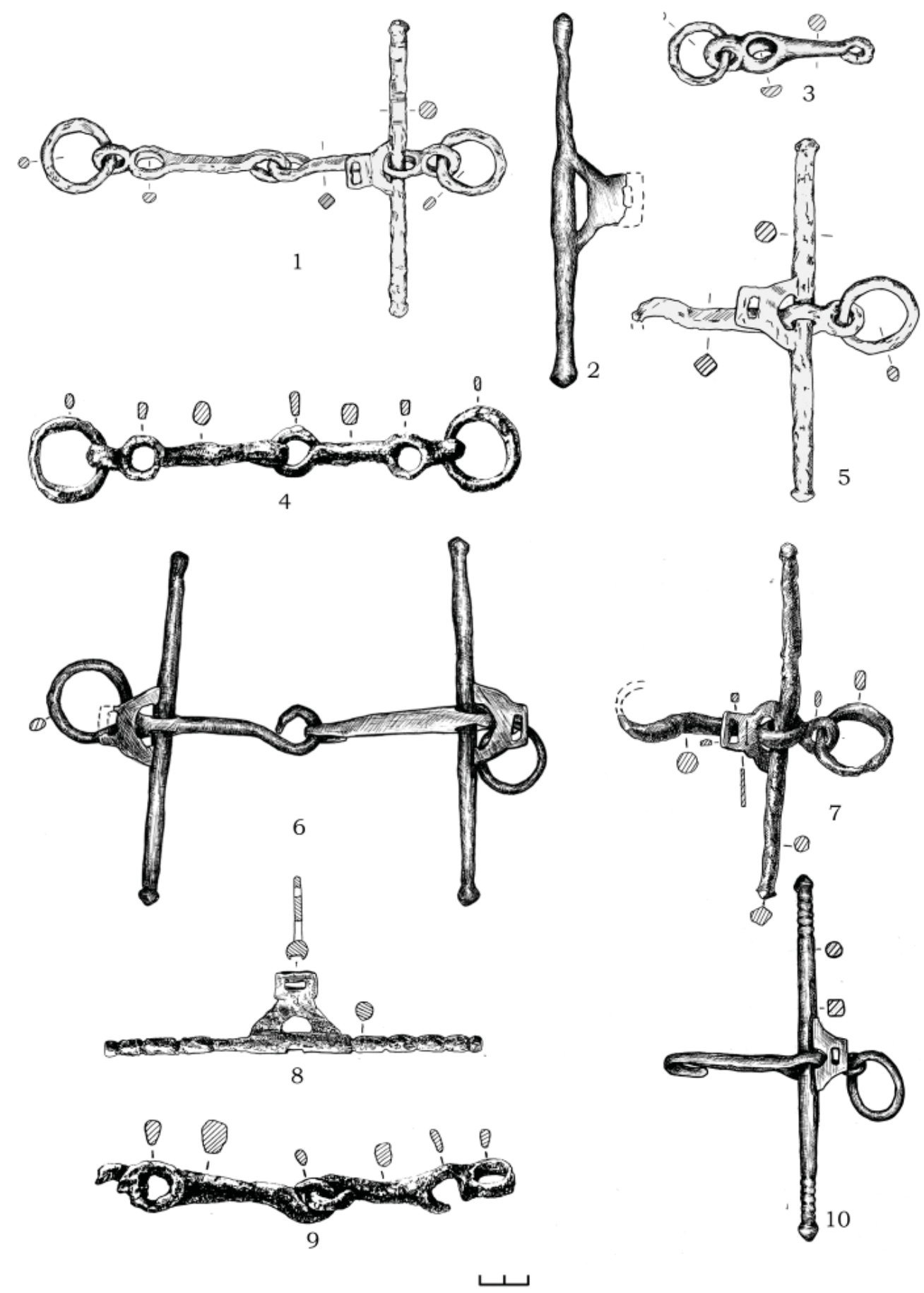

Рис. 2. Удила с археологического комплекса у с. Маяки.

Fig. 2. Bit from an archaeological complex near Mayaki village. 

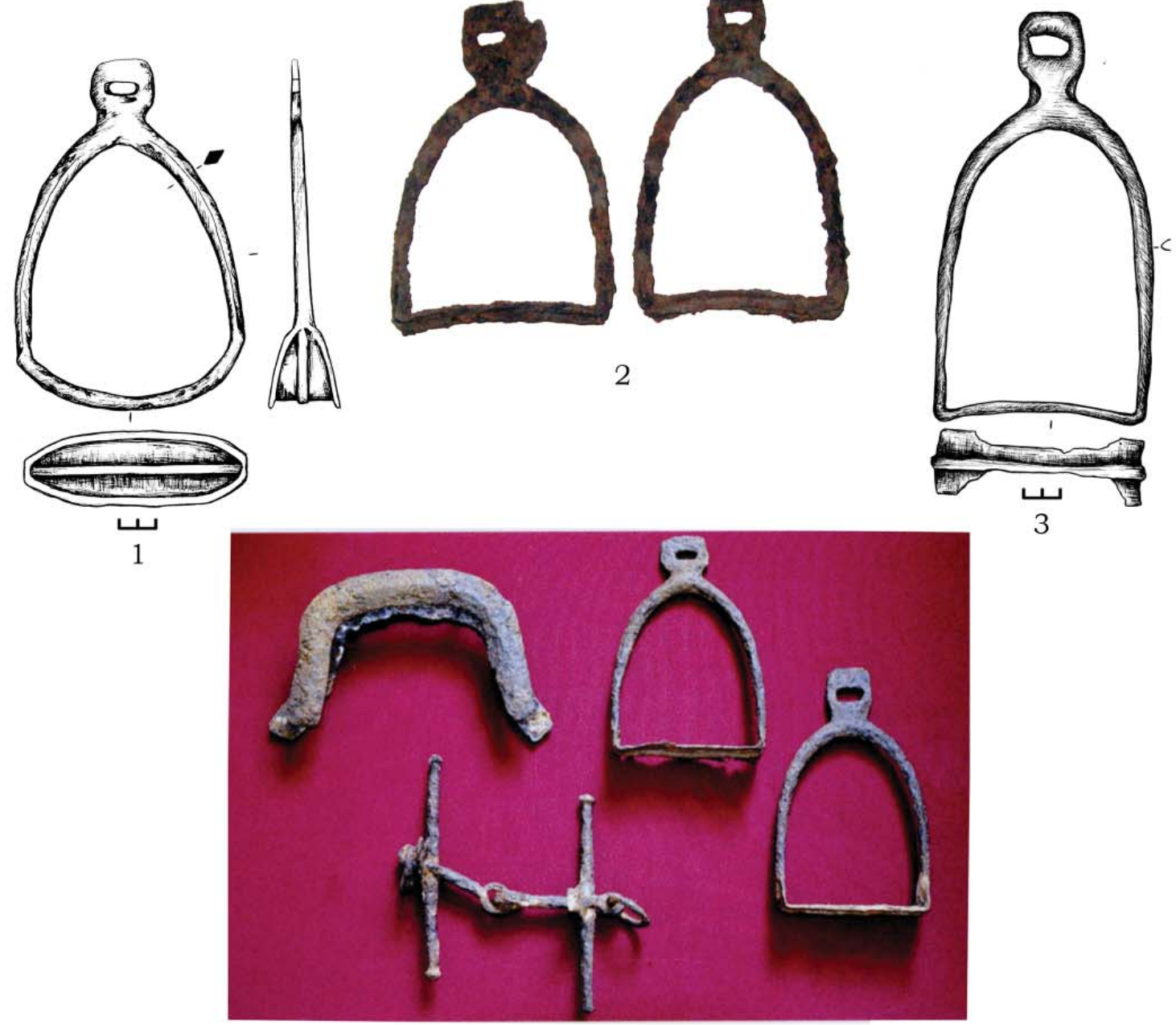

4
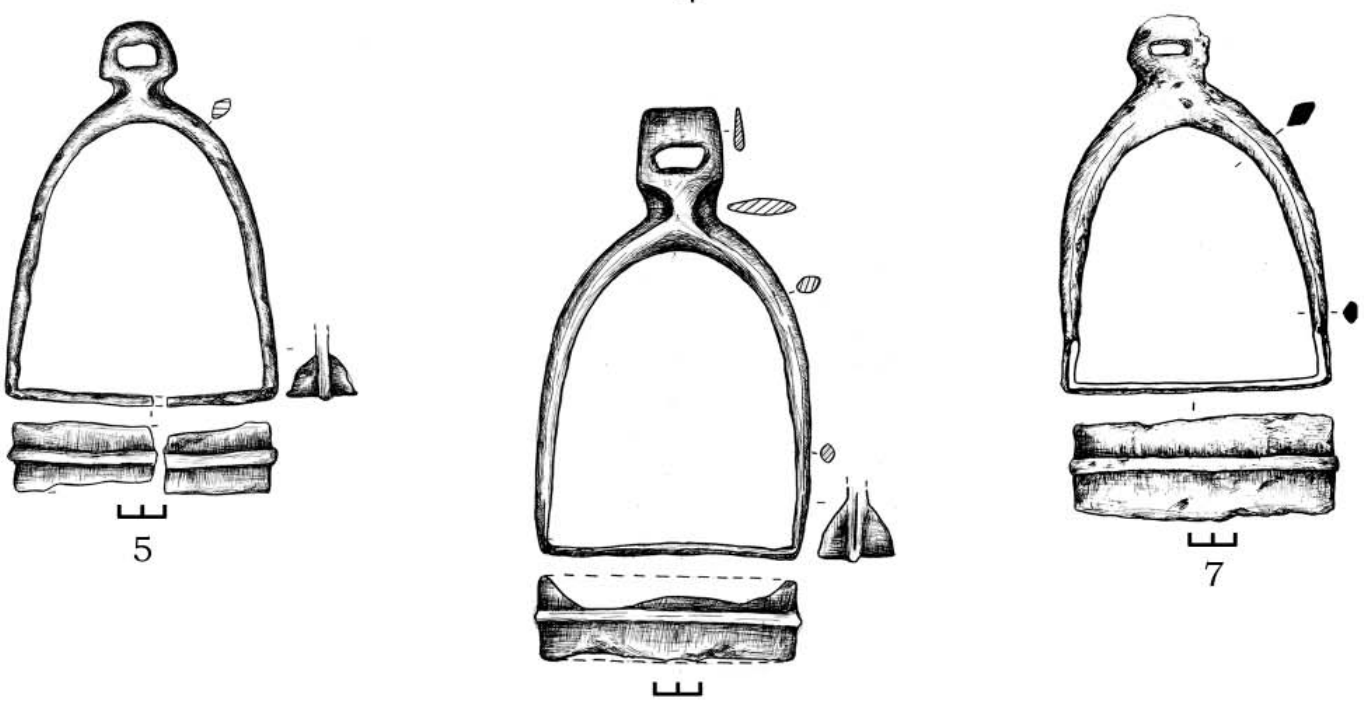

6

Рис. 3. Стремена с археологического комплекса у с. Маяки: 1-3, 5-7 - раскопки В.К. Михеева; 4 - по Матеріальна та духовна культура, 2017, Ілл. 54.

Fig. 3. Stirrups from the archaeological complex near Mayaki village: 1-3, 5-7 - excavations by V. K. Mikheev; 4 - after Material and Spiritual Culture, 2017, Ill. 54. 

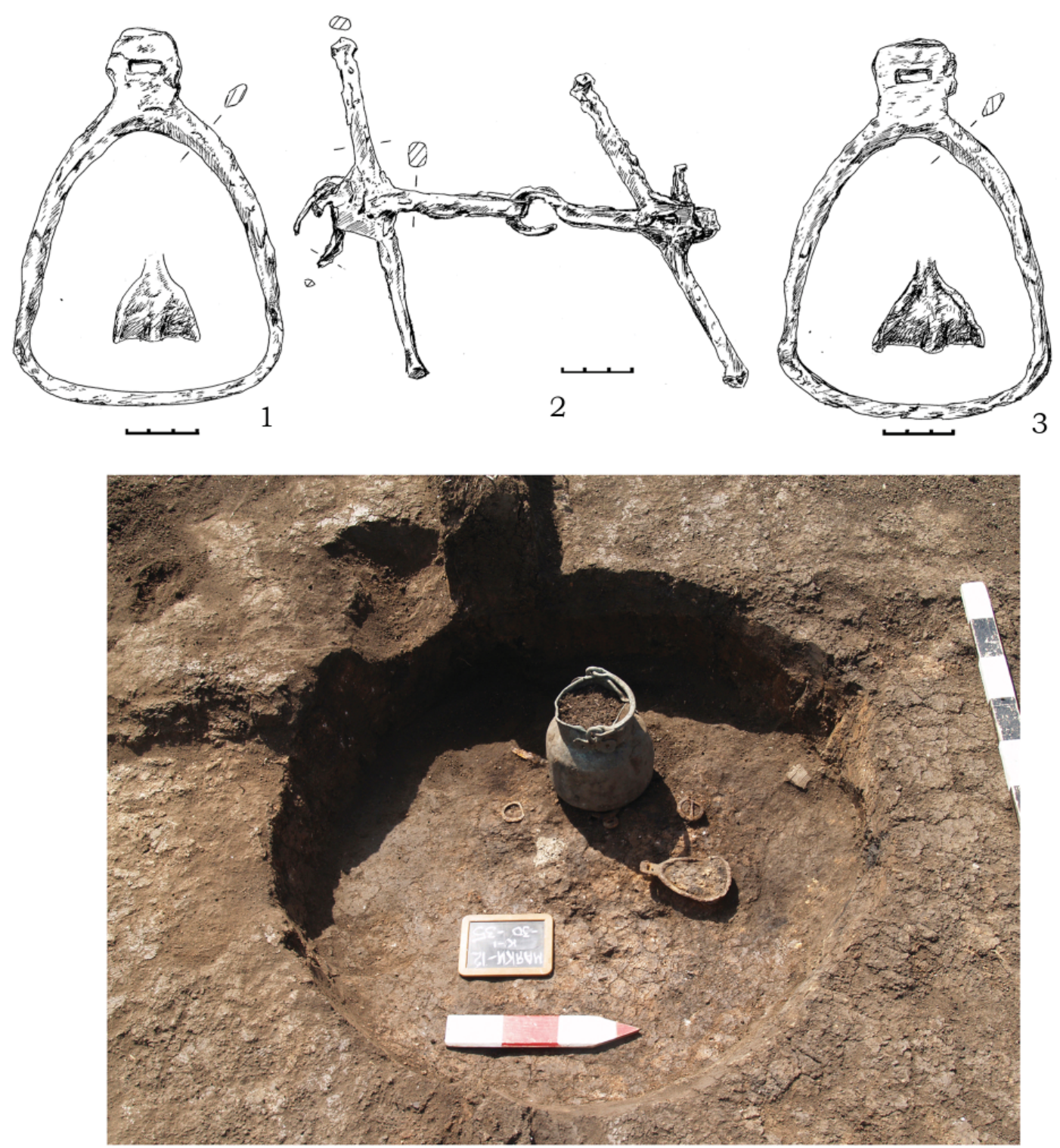

4

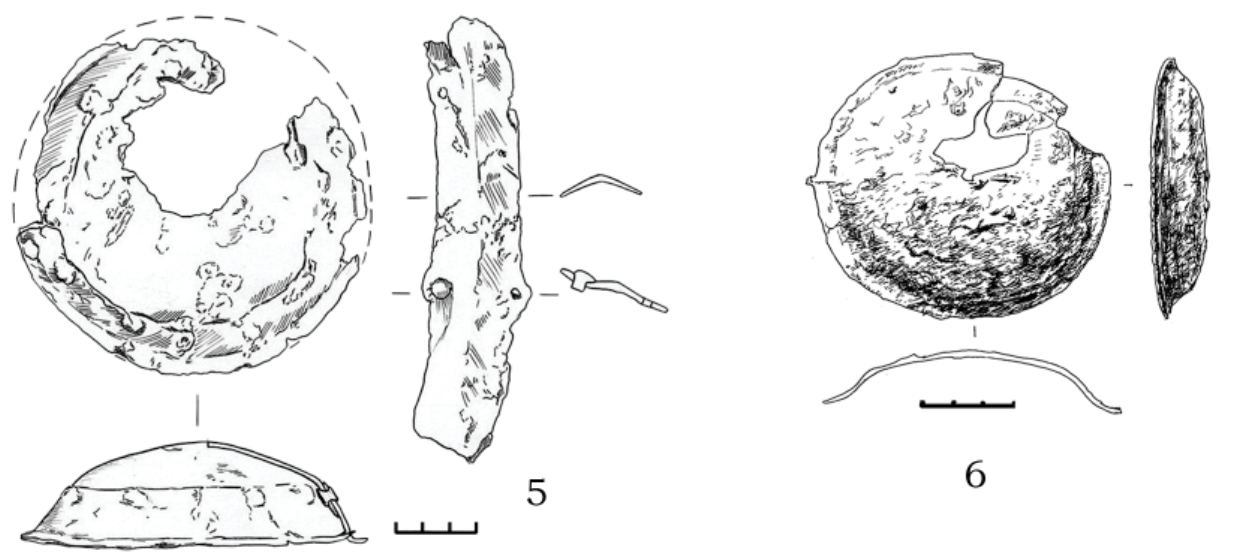

Рис. 4. Детали конской упряжи из комплекса 2012 г., найденного на городище у с. Маяки: 1-3, 6 - предметы из комплекса; 4 - фото комплекса; 5 - бляха из клада железных вещей, найденного у г. Николаевка.

Fig. 4. Horse harness details from the 2012 complex discovered at the site of a settlement near Mayaki village: 1-3, 6items from the complex; 4 - photo of the complex; 5 - plaque from a hoard of iron items discovered near Nikolaevka. 


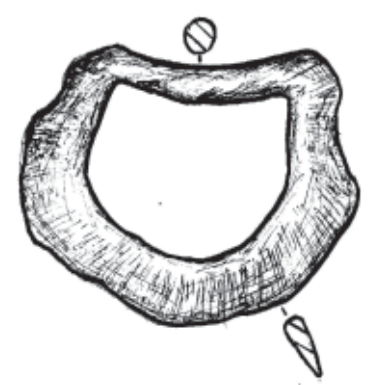

1

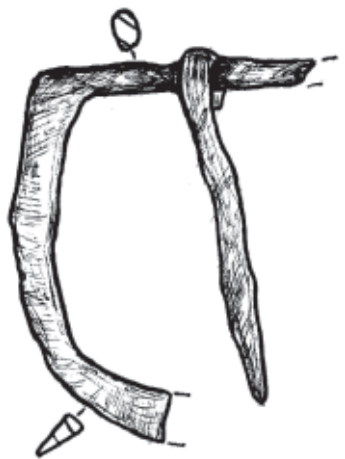

4

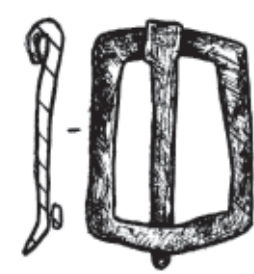

7

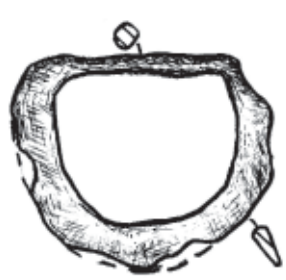

5
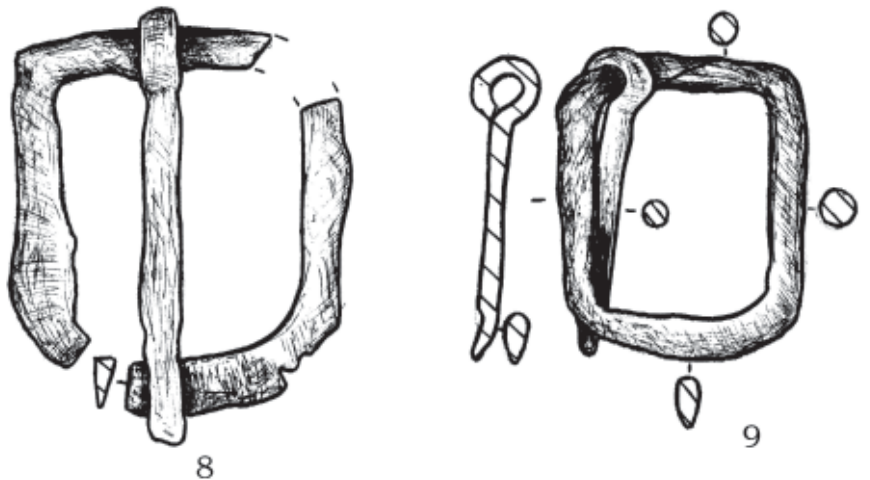

Рис. 5. Железные пряжки с археологического комплекса у с. Маяки. Раскопки В.К.Михеева. Fig. 5. Iron buckles from an archaeological site near Mayaki village. Excavations by V. K. Mikheev. 

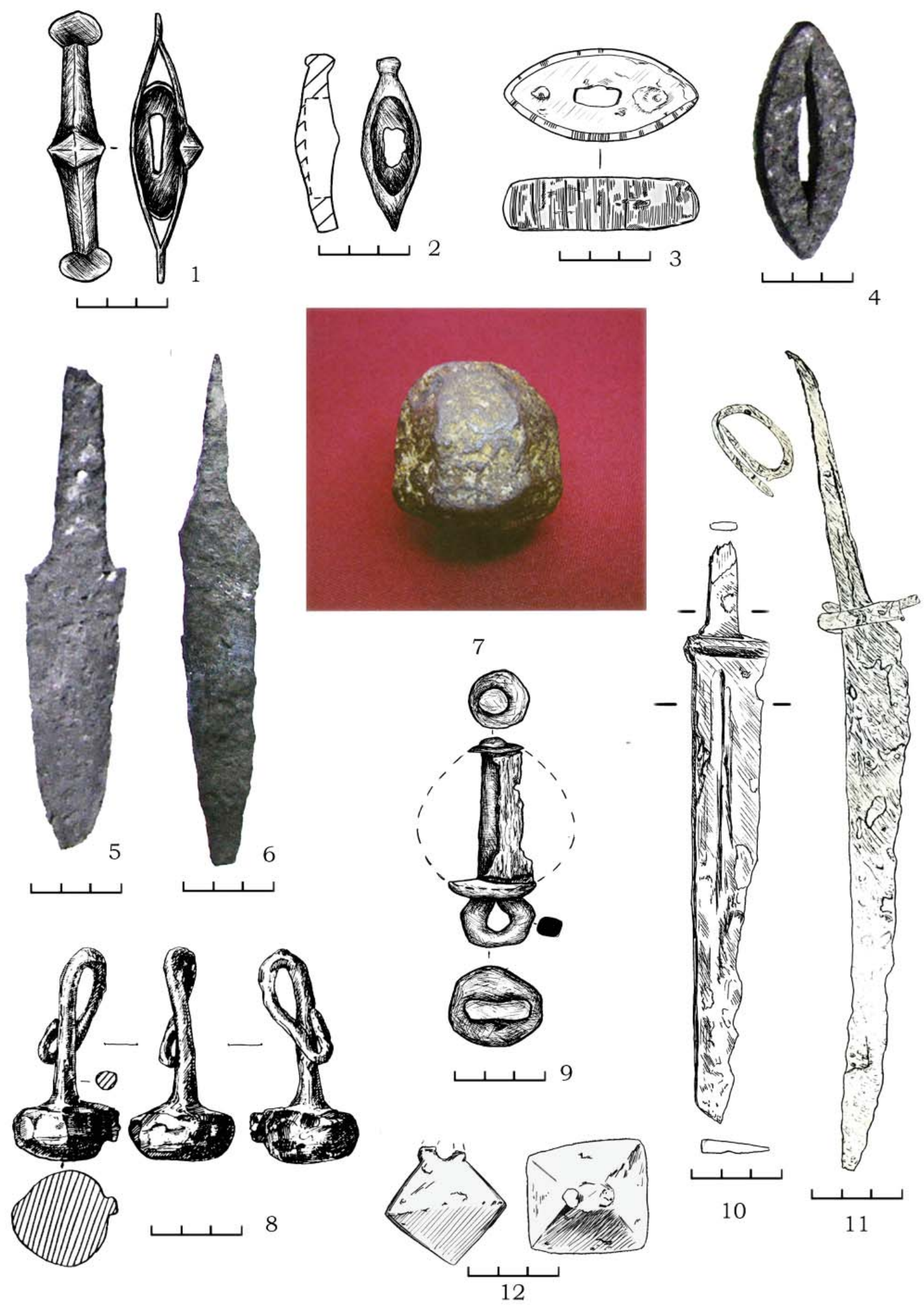

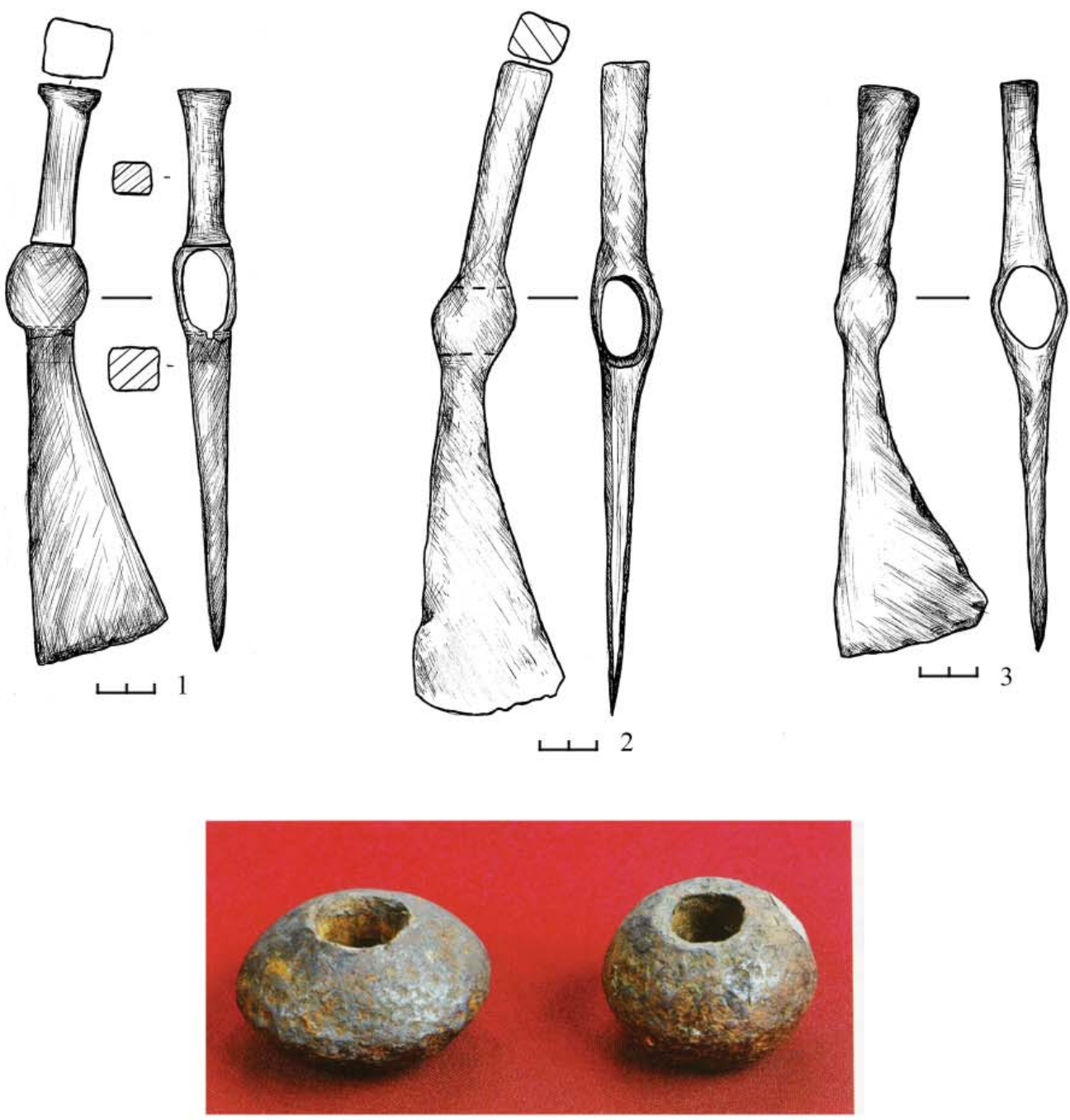

4
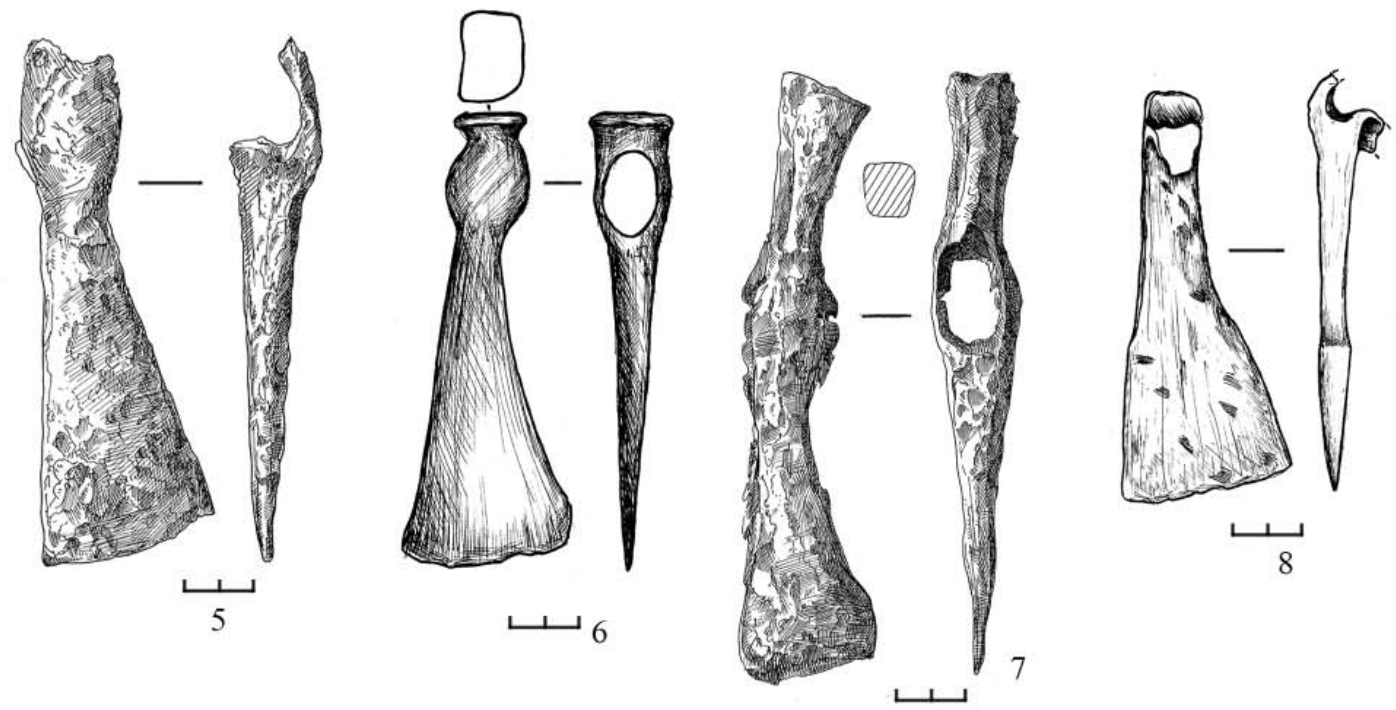

Рис. 7. Боевые топорики и булавы с археологического комплекса у с. Маяки:

1-3, 6 - раскопки В.К. Михеева; 4 - по Матеріальна та духовна культура, 2017, Ілл. 71.

Fig. 7. Battle axes and maces from an archaeological complex near Mayaki village:

1-3, 6-excavations by V. K. Mikheev; 4 - after Material and Spiritual Culture, 2017, Ill. 71. 

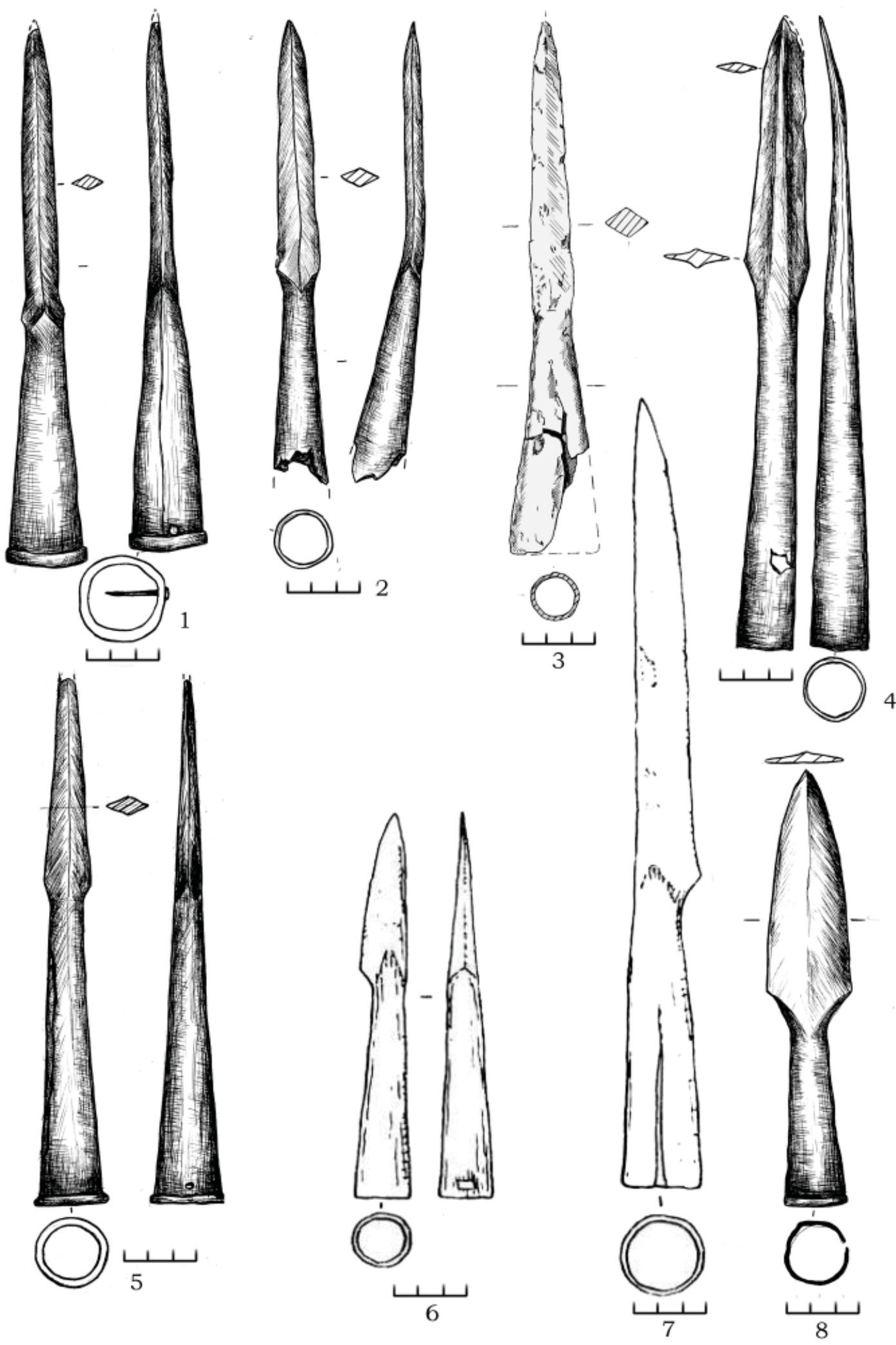

Рис. 8. Наконечники копий с археологического комплекса у с. Маяки по В.К. Михееву (6-7 - по Михеев, 1985, рис. 30, 17-18).

Fig. 8. Spearheads from an archaeological complex near Mayaki village after V. K. Mikheev (6-7 - after Mikheev, 1985, fig. 30, 17-18). 


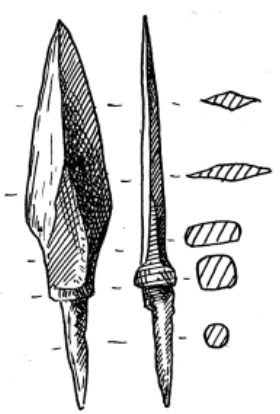

1

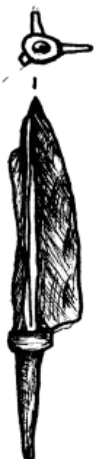

2
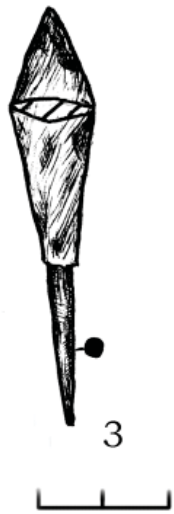
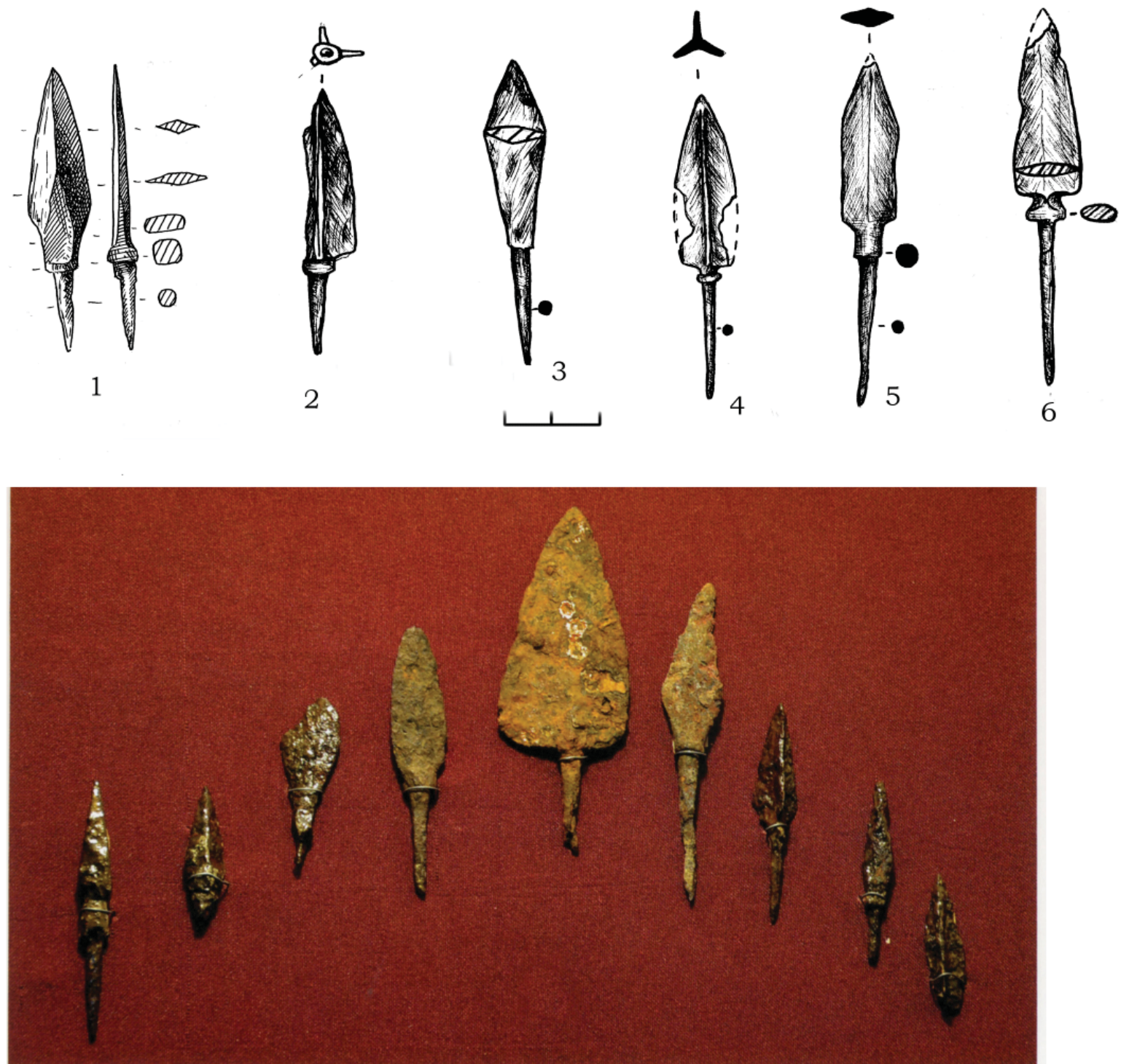

7

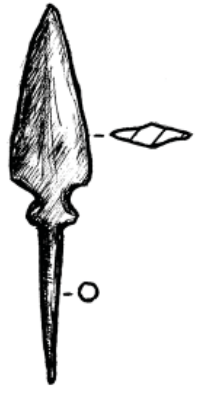

8
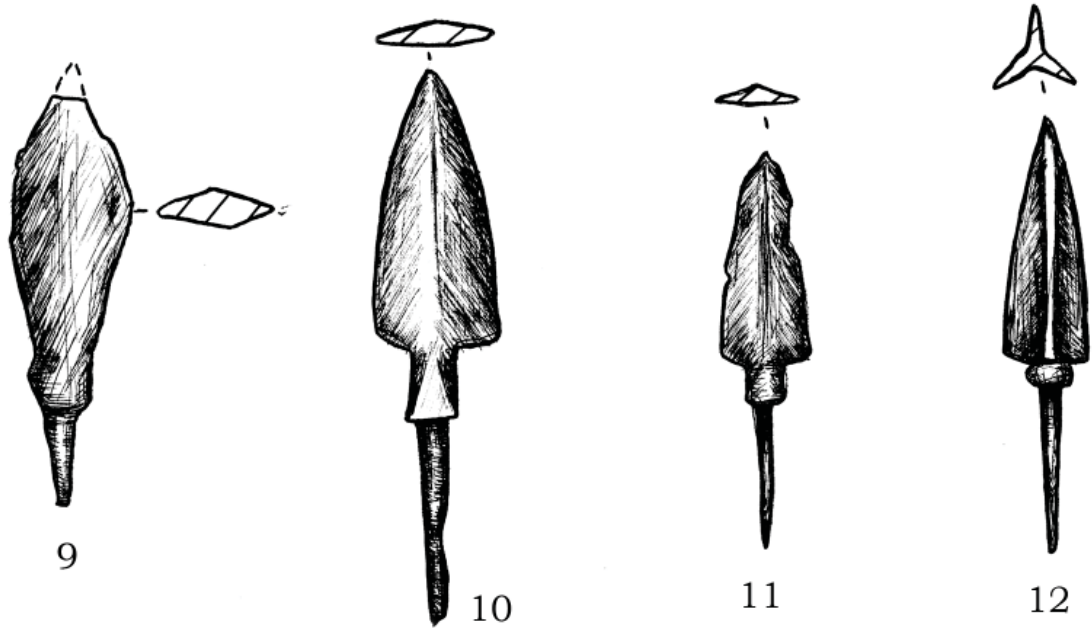

Рис. 9. Наконечники стрел с археологического комплекса у с. Маяки: 2-6 - по В.К.Михееву; 7 - по Матеріальна та духовна культура, 2017, Ілл. 65.

Fig. 9. Arrowheads from an archaeological complex near Mayaki village: $2-6$ - after V. K. Mikheev; 7 - after Material and Spiritual Culture, 2017, Ill. 65. 